Prepared in cooperation with the U.S. Fish and Wildlife Service

\title{
Characterization of Sediment and Measurement of Groundwater Levels and Temperatures, Camas National Wildlife Refuge, Eastern Idaho
}

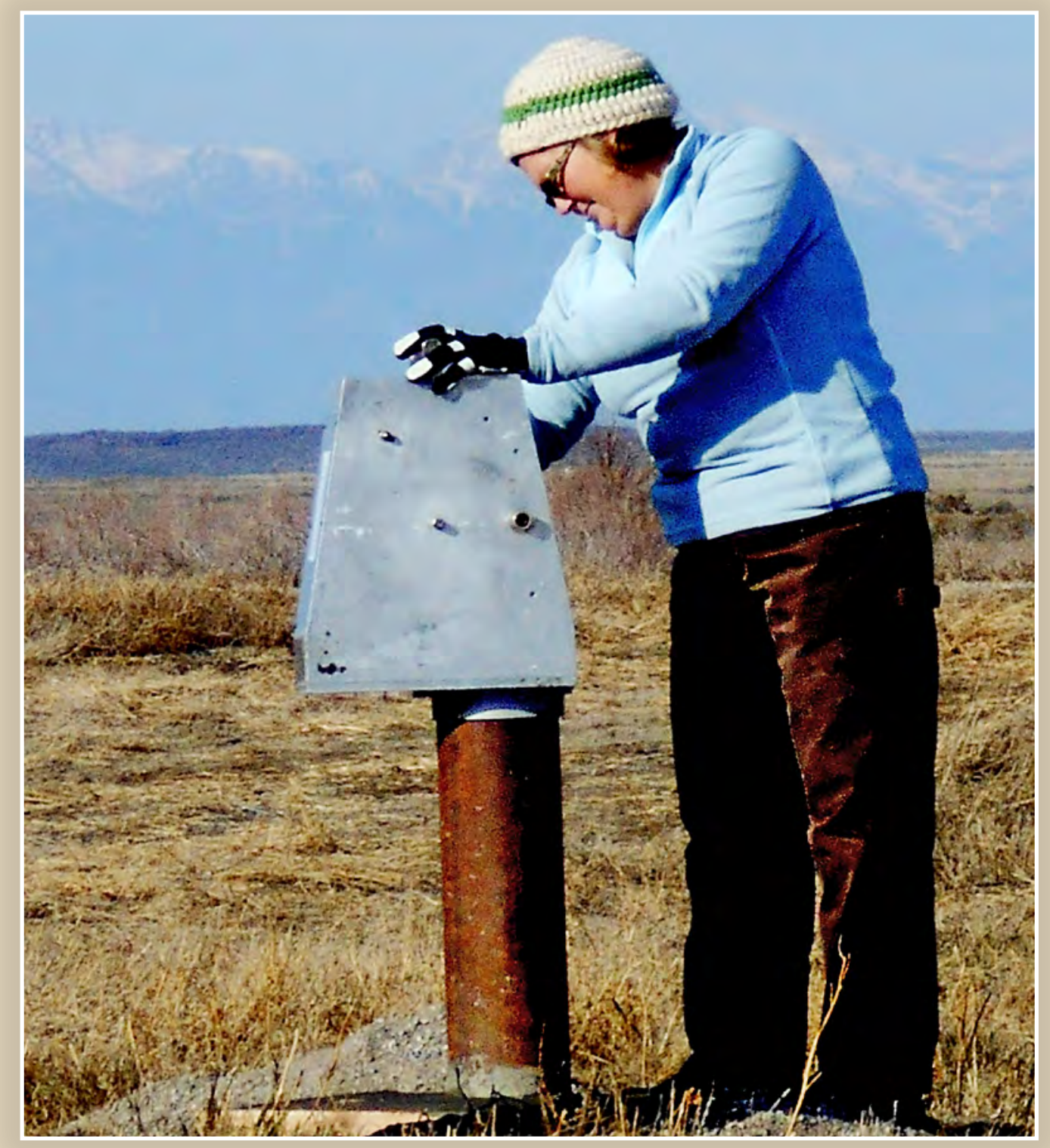

Data Series 1024

U.S. Department of the Interior

U.S. Geological Survey 
Cover: Photograph showing a U.S. Geological Survey Hydrologic Technician measuring water levels at monitoring well CNWR-P1, Camas National Wildlife Refuge, eastern Idaho. Photograph shows part of the eastern Snake River Plain in the foreground and the Lemhi Mountains in the background. Photograph by Gordon Rattray, U.S. Geological Survey, December 5, 2014. 


\section{Characterization of Sediment and Measurement of Groundwater Levels and Temperatures, Camas National Wildlife Refuge, Eastern Idaho}

By Brian V. Twining and Gordon W. Rattray

Prepared in cooperation with the U.S. Fish and Wildlife Service

Data Series 1024 


\title{
U.S. Department of the Interior SALLY JEWELL, Secretary
}

\section{U.S. Geological Survey Suzette M. Kimball, Director}

\author{
U.S. Geological Survey, Reston, Virginia: 2016
}

For more information on the USGS - the Federal source for science about the Earth, its natural and living resources, natural hazards, and the environment-visit http://www.usgs.gov or call 1-888-ASK-USGS.

For an overview of USGS information products, including maps, imagery, and publications, visit http://store.usgs.gov/.

Any use of trade, firm, or product names is for descriptive purposes only and does not imply endorsement by the U.S. Government.

Although this information product, for the most part, is in the public domain, it also may contain copyrighted materials as noted in the text. Permission to reproduce copyrighted items must be secured from the copyright owner.

The findings and conclusions in this article are those of the author(s) and do not necessarily represent the views of the U.S. Fish and Wildlife Service.

Suggested citation:

Twining, B.V., and Rattray, G.W., 2016, Characterization of sediment and measurement of groundwater levels and temperatures, Camas National Wildlife Refuge, eastern Idaho: U.S. Geological Survey Data Series 1024, 23 p., http://dx.doi.org/10.3133/ds1024.

ISSN 2327-638X (online) 


\section{Contents}

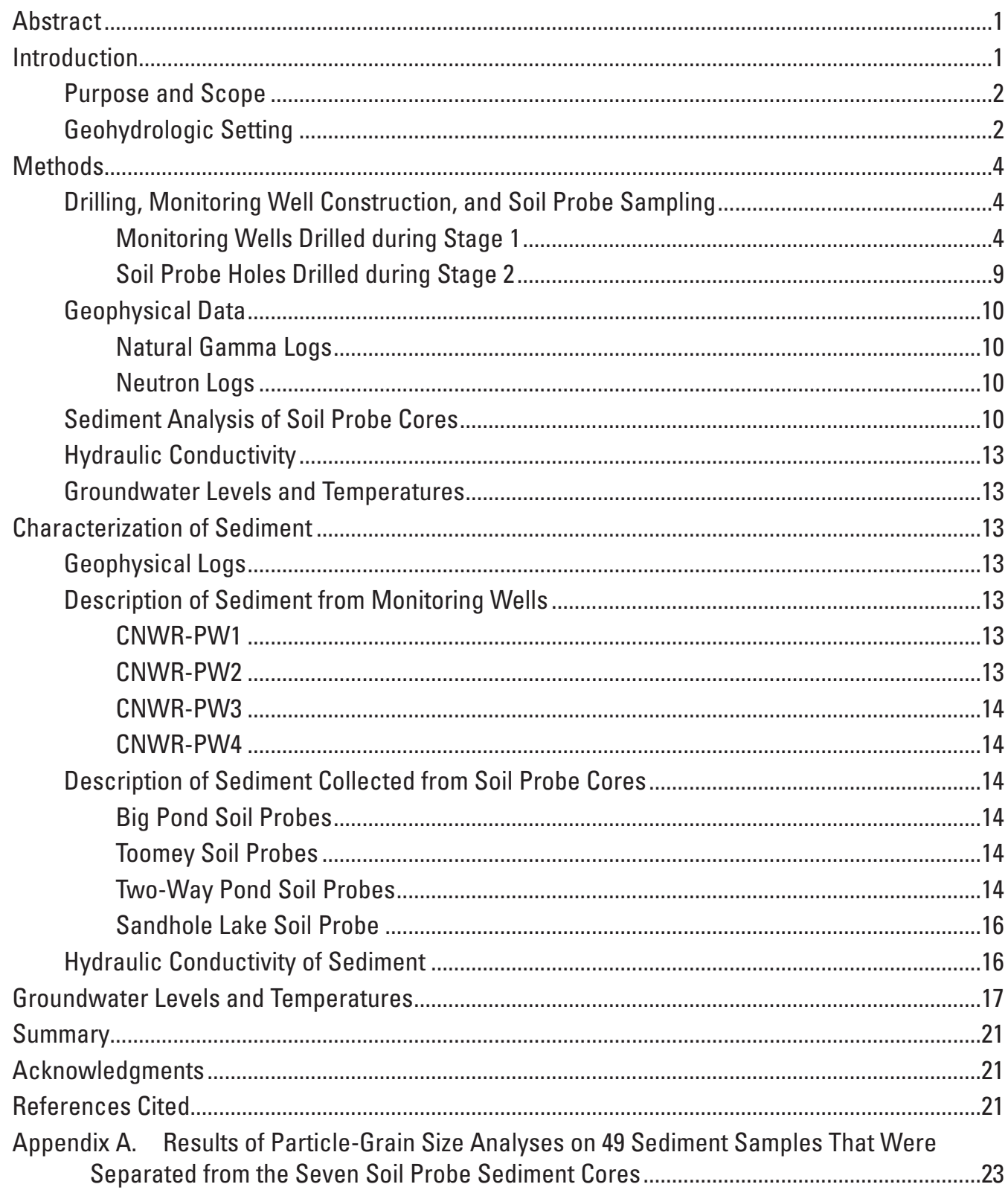




\section{Figures}

1. Map showing surface geology and locations of monitoring wells and soil probe holes at the Camas National Wildlife Refuge, eastern Idaho

2. Geophysical and construction logs run from total depth to land surface and lithologic logs described from drillers' notes and geophysical logs for monitoring well CNWR-PW1, Camas National Wildlife Refuge, eastern Idaho.

3. Geophysical and construction logs run from total depth to land surface and lithologic logs described from drillers' notes and geophysical logs for monitoring well CNWR-PW2, Camas National Wildlife Refuge, eastern Idaho.

4. Geophysical and construction logs run from total depth to land surface and lithologic logs described from drillers' notes and geophysical logs for monitoring well CNWR-PW3, Camas National Wildlife Refuge, eastern Idaho.

5. Geophysical and construction logs run from total depth to land surface and lithologic logs described from drillers' notes and geophysical logs for monitoring well CNWR-PW4, Camas National Wildlife Refuge, eastern Idaho.

6. Photographs showing soil probes and samples prepared for particle-size analysis, Camas National Wildlife Refuge, eastern Idaho

7. Vertical sediment profiles at soil probe sites, Camas National Wildlife Refuge, eastern Idaho

8. Graph showing water level and temperature at site CNWR-P1, Camas National Wildlife Refuge, eastern Idaho.

9. Graph showing water level and temperature at site CNWR-P2A, Camas National Wildlife Refuge, eastern Idaho.

10. Graph showing water level and temperature at site CNWR-P2B, Camas National Wildlife Refuge, eastern Idaho.

11. Graph showing water level and temperature at site CNWR-P3A, Camas National Wildlife Refuge, eastern Idaho.

12. Graph showing water level and temperature at site CNWR-P3B, Camas National Wildlife Refuge, eastern Idaho.....

13. Graph showing water level and temperature at site CNWR-P4A, Camas National Wildlife Refuge, eastern Idaho.

14. Graph showing water level and temperature at site CNWR-P4B, Camas National Wildlife Refuge, eastern Idaho.

\section{Tables}

1. Location and construction information for monitoring wells, Camas National Wildlife Refuge, eastern Idaho.

2. Location and percentage of recovery for soil probe holes, Camas National Wildlife Refuge, eastern Idaho

3. Particle-size characteristics from particle grain-size analysis of sediment samples from soil probe sites and classification used for soil probe analysis, Camas National Wildlife Refuge, eastern Idaho 


\section{Conversion Factors}

U.S. customary units to International System of Units

\begin{tabular}{lcl}
\hline \multicolumn{1}{c}{ Multiply } & By & \multicolumn{1}{c}{ To obtain } \\
\hline inch (in.) & Length & \\
foot (ft) & 25.4 & millimeter $(\mathrm{mm})$ \\
mile (mi) & 0.3048 & meter $(\mathrm{m})$ \\
& 1.609 & kilometer $(\mathrm{km})$ \\
\hline square mile $\left(\mathrm{mi}^{2}\right)$ & Area & hectare $(\mathrm{ha})$ \\
square mile $\left(\mathrm{mi}^{2}\right)$ & 259.0 & square kilometer $\left(\mathrm{km}^{2}\right)$ \\
\hline & 2.590 & joule $(\mathrm{J})$ \\
\hline electronvolt $(\mathrm{eV})$ & Energy \\
\hline & $6.242^{18}$ & \\
\hline foot per day (ft/d) & Hydraulic conductivity & meter per day $(\mathrm{m} / \mathrm{d})$ \\
\hline
\end{tabular}

International System of Units to U.S. Customary Units

\begin{tabular}{|c|c|c|}
\hline Multiply & By & To obtain \\
\hline \multicolumn{3}{|c|}{ Length } \\
\hline millimeter (mm) & 0.0394 & inch (mm) \\
\hline
\end{tabular}

Temperature in degrees Celsius $\left({ }^{\circ} \mathrm{C}\right)$ may be converted to degrees Fahrenheit $\left({ }^{\circ} \mathrm{F}\right)$ as follows:

$$
{ }^{\circ} \mathrm{F}=\left(1.8 \times{ }^{\circ} \mathrm{C}\right)+32 .
$$

\section{Datums}

Vertical coordinate information is referenced to the North American Vertical Datum of 1988 (NAVD 88).

Horizontal coordinate information is referenced to the North American Datum of 1927 (NAD 27).

Altitude, as used in this report, refers to distance above the vertical datum.

\section{Abbreviations and Acronyms}
bls below land surface
ESRP eastern Snake River Plain
Refuge Camas National Wildlife Refuge
USGS U.S. Geological Survey 



\title{
Characterization of Sediment and Measurement of Groundwater Levels and Temperatures, Camas National Wildlife Refuge, Eastern Idaho
}

\author{
By Brian V. Twining and Gordon W. Rattray
}

\begin{abstract}
The Camas National Wildlife Refuge (Refuge) in eastern Idaho, established in 1937, contains wetlands, ponds, and wet meadows that are essential resting and feeding habitat for migratory birds and nesting habitat for waterfowl. Initially, natural sources of water supported these habitats. However, during the past few decades, climate change and changes in surrounding land use have altered and reduced natural groundwater and surface water inflows such that the wetlands, ponds, and wet meadows are now maintained through water management and groundwater pumping. These water management activities have proven to be inefficient and costly, prompting the Refuge to develop alternative water management options that are more efficient and less expensive. The U.S. Geological Survey, in cooperation with the U.S. Fish and Wildlife Service, is studying the hydrogeology at the Refuge to provide information for developing alternative water management options.

The hydrogeologic studies at the Refuge included characterizing the type, distribution, and hydraulic conductivity of surficial sediments and measuring water levels and temperatures in monitoring wells. Four monitoring wells and seven soil probe coreholes were drilled at the Refuge. Seven water level and temperature data loggers were installed in the wells and water levels and temperatures were continuously recorded from November 2014 to June 2016. Sediment cores were collected from the coreholes and sediment type and distribution were characterized from drillers' notes, geophysical logs, corehole samples, and particle grain-size analysis. The hydraulic conductivities of sediments were estimated using the measured average grain size and the assumed textural maturity of the sediment, and ranged from about 20 to 290 feet per day.
\end{abstract}

\section{Introduction}

The Camas National Wildlife Refuge (Refuge) was established in 1937, primarily "as a refuge and breeding ground for migratory birds and other wildlife" (U.S. Fish and Wildlife Service, 2012, p. 5), with wetlands, ponds, and wet meadows providing essential resting and feeding habitat for migratory birds and nesting habitat for waterfowl (U.S. Fish and Wildlife Service, 2012). Initially, natural groundwater and surface-water inflows and precipitation were sufficient to maintain the wetland habitat (Henry and Heitmeyer, 2014). However, in recent years changes in climate and surrounding land use have altered and decreased natural groundwater and surface-water inflows (Gillis and others, 2011; U.S. Fish and Wildlife Service, 2012; Henry and Heitmeyer, 2014). Consequently, "the existing complex of wetlands, ponds and wet meadows is maintained through water management and groundwater pumping" (U.S. Fish and Wildlife Service, 2012, p. 27). Groundwater pumping and conveyance of water through miles of unlined ditches and canals has proven to be an inefficient and costly water management alternative for the Refuge (Brain Wehausen, U.S. Fish and Wildlife Service, oral commun., 2014), prompting the Refuge to develop alternative water management options that are more efficient and less expensive. The U.S. Geological Survey (USGS) is studying the hydrogeology at the Refuge to provide information for developing alternative water management options. 


\section{Purpose and Scope}

The purpose of this study is to characterize the type, distribution, and hydraulic conductivity of surficial sediments (sediment above the first basalt contact) and to measure groundwater levels and temperatures at the Refuge. Four monitoring wells and seven soil probe coreholes were drilled and instrumented at the Refuge.

\section{Geohydrologic Setting}

The $16.6 \mathrm{mi}^{2}$ Refuge is located at about $4,790 \mathrm{ft}$ altitude on the eastern Snake River Plain (ESRP) in eastern Idaho (fig. 1). The climate is desert to semi-desert, with annual precipitation estimated at less than $10 \mathrm{in}$. and annual temperature extremes that range from about -18 to more than $32{ }^{\circ} \mathrm{C}$ (Rattray and Ginsbach, 2013; Henry and Heitmeyer, 2014). Land use surrounding the Refuge includes rangeland and irrigated agriculture (U.S. Fish and Wildlife Service, 2012).

Near the Refuge, the ESRP is a bimodal volcanic province consisting of Miocene to Pliocene rhyolite overlain by a thick accumulation of Quaternary olivine basalt flows plus surficial and interbedded Quaternary sediment (Rattray and Ginsbach, 2013). The surface geology at the Refuge ranges from, in a northwest-to-southeast direction, basalt, fluvial and lacustrine sediment, and eolian and alluvial sediment (fig. 1). The thickness of surficial sediments range from $0 \mathrm{ft}$ in the northwestern part of the Refuge to more than $80 \mathrm{ft}$ in the southeastern part.

Surface hydrologic features at the Refuge include about $10 \mathrm{mi}^{2}$ of ponds, lakes, and wetlands, three streams, and about $13.2 \mathrm{mi}$ of canals and ditches that are used to transport surface water or groundwater from points of diversion or pumping to places of use on the Refuge (U.S. Fish and Wildlife Service, 2012). The surface area of ponds and lakes (wet or dry) occupies approximately 25 percent of the Refuge, and the total surface area of wetland habitat comprises about 60 percent of the Refuge (U.S. Fish and Wildlife Service, 2012). Camas Creek is the only stream that provides significant natural surface water inflow to the Refuge and, during wet years, may flow through the Refuge during April, May, and June (Rattray and Ginsbach, 2013).

Groundwater underlying the Refuge is part of the ESRP aquifer, and groundwater levels have fluctuated during the past century primarily because of changing irrigation practices (U.S. Fish and Wildlife Service, 2012). Use of flood irrigation near the Refuge caused groundwater levels to rise about $100 \mathrm{ft}$ prior to 1930 (Stearns and others, 1939; Goodell, 1988; Garabedian, 1992; U.S. Fish and Wildlife Service, 2012). Use of groundwater for irrigation increased significantly during the 1950s, 1960s, and 1970s (Spinazola, 1994), and since the mid-1970s groundwater levels have declined about 15-20 ft (U.S. Fish and Wildlife Service, 2012). 


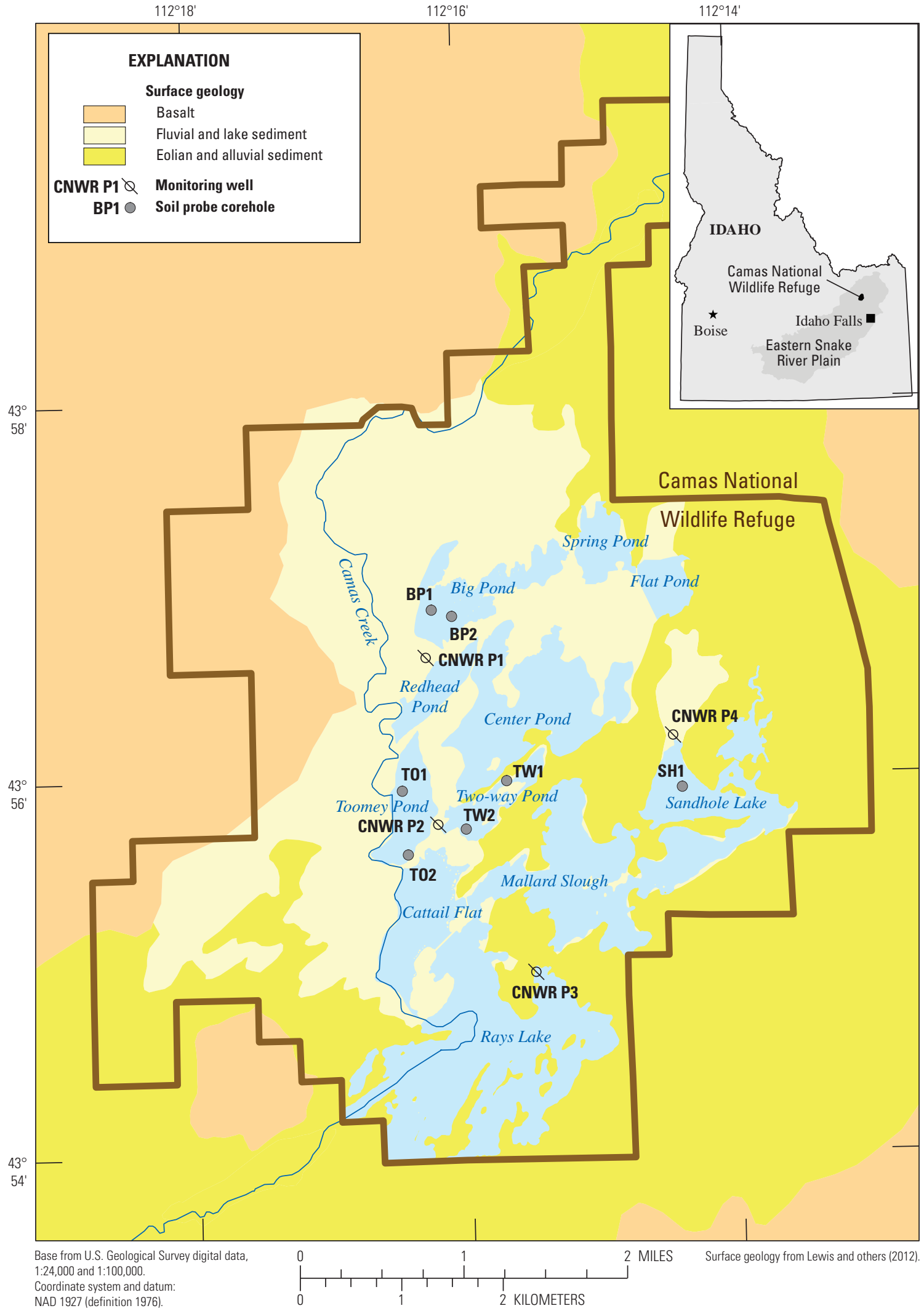

Figure 1. Surface geology and locations of monitoring wells and soil probe holes at the Camas National Wildlife Refuge, eastern Idaho. 


\section{Methods}

\section{Drilling, Monitoring Well Construction, and Soil Probe Sampling}

The USGS completed drilling, monitoring well construction, and soil probe sampling in two stages. During the first stage, from October 20, 2014, to November 3, 2014, four monitoring wells (fig. 1) were drilled and constructed using 7-in. hollow stem augers and completed to select depths with single or dual screen intervals. During the second stage, from December 9, 2014, to December 12, 2014, seven 2.5-in. soil probe coreholes were drilled and sediment cores were collected. The locations of the monitoring wells (table 1) were surveyed from a U.S. Coast and Geodetic survey point at the Refuge. After construction, data loggers were installed in the monitoring wells and set to continuously record water level and temperature data between November 2014 and June 2016.

\section{Monitoring Wells Drilled during Stage 1}

Auger drilling was completed using a $\mathrm{GEFCO}^{\mathrm{TM}}$ SD-300 drill rig. The rig was used to drive hollow stem augers to the first basalt contact, or until drilling could not go deeper. Depth to the first basalt contact was about $19 \mathrm{ft}$ below land surface (bls) in well CNWR-P1. The basalt contact was not reached in the other wells (CNWR-PW2, CNWR-PW3, and CNWR-PW4) after drilling to depths ranging from 60 to $80 \mathrm{ft}$ bls. Drillers' notes included sediment descriptions from soil returns as auger drilling progressed.

After drilling, geophysical logs were collected through hollow stem augers. Monitoring wells were then constructed with 5-ft screened intervals (table 1), where the screened zones were selected based on drillers' notes and geophysical log data. CNWR-PW1 was completed with a single screened interval between 13 and $18 \mathrm{ft}$; CNWR-PW2 was completed with two screened intervals located from 28 to $33 \mathrm{ft}$ bls and from 48 to $53 \mathrm{ft}$ bls; CNWR-PW3 was completed with two screened intervals located from 28 to $33 \mathrm{ft}$ bls and from 61 to $66 \mathrm{ft}$ bls; and CNWR-PW4 was completed with two screened intervals located from 40 to 45 and from 72 to $77 \mathrm{ft} \mathrm{bls}$ (table 1).

Monitoring well construction, including placement of PVC pipe, sand, and bentonite seal, was completed using hollow stem augers to prevent the drilled hole from collapsing when setting construction material. This was accomplished by setting and pouring material while pulling auger flights out in $5 \mathrm{ft}$ sections. For monitoring wells with two screened intervals, 1.25-in. (31.8 mm), schedule-80 PVC pipe was lowered and placed on the bottom and coarse silica sand was poured in behind the screened zone. Silica sand was tagged and continuously added until it was at a level above the screen. Once the silica sand was placed, coated bentonite pellets were poured in to seal between the lower and upper screened intervals. Adding bentonite pellets was done in sequence with pulling out auger flights until the upper screened interval was reached. The upper screened zone was set in similar sequence, with six-ninths coarse silica sand followed by granular bentonite casing seal in conjunction with tagging the material and pulling augers out of the ground. This similar construction process was repeated for all monitoring wells. Steel surface casing, cement pad, and brass survey markers were set after lines for the data loggers were installed. Water was flushed down each line after installation to clear and develop screened sections for each monitoring well. Final construction diagrams of the monitoring wells are displayed in figures 2-5.

Table 1. Location and construction information for monitoring wells, Camas National Wildlife Refuge, eastern Idaho.

[L ocal name: Local well identifier used in this study. Location of well is shown in figure 1. Site identifier: Unique numerical identifier used to access well data (http://waterdata.usgs.gov/nwis). L ongitude, L atitude, and Altitude: Survey taken at brass survey marker (brass cap) located adjacent to well head on cement pad. Depth drilled: Total depth drilled in feet. Screen interval: Interval screened by monitor well. Abbreviations: ft bls, feet below land surface; NAD 27, North American Datum of 1927; NAVD 88, North American Vertical Datum of 1988]

\begin{tabular}{lcccccc}
\hline \multicolumn{1}{c}{ Local name } & Site identifier & $\begin{array}{c}\text { Latitude } \\
\text { (NAD 27) }\end{array}$ & $\begin{array}{c}\text { Longitude } \\
\text { (NAD 27) }\end{array}$ & $\begin{array}{c}\text { Altitude } \\
\text { (NAVD 88) }\end{array}$ & $\begin{array}{c}\text { Depth drilled } \\
\text { (ft bls) }\end{array}$ & $\begin{array}{c}\text { Screen interval } \\
\text { (ft bls) }\end{array}$ \\
\hline CNWR-P1 & 435632112161301 & $43^{\circ} 56^{\prime} 38.9^{\prime \prime}$ & $112^{\circ} 16^{\prime} 15.8^{\prime \prime}$ & $4,796.48$ & 19 & $13-18$ \\
CNWR-P2b & 435546112160901 & $43^{\circ} 55^{\prime} 45.6^{\prime \prime}$ & $112^{\circ} 16^{\prime} 11.9^{\prime \prime}$ & $4,799.25$ & 60 & $28-33$ \\
CNWR-P2a & 435546112160902 & $43^{\circ} 55^{\prime} 45.6^{\prime \prime}$ & $112^{\circ} 16^{\prime} 11.9^{\prime \prime}$ & $4,799.25$ & 60 & $48-53$ \\
CNWR-P3b & 435458112152601 & $43^{\circ} 54^{\prime} 58.1^{\prime \prime}$ & $112^{\circ} 15^{\prime} 30.0^{\prime \prime}$ & $4,793.00$ & 69 & $28-33$ \\
CNWR-P3a & 435458112152602 & $43^{\circ} 54^{\prime} 58.1^{\prime \prime}$ & $112^{\circ} 15^{\prime} 30.0^{\prime \prime}$ & $4,793.00$ & 69 & $61-66$ \\
CNWR-P4b & 435611112142001 & $43^{\circ} 56^{\prime} 13.2^{\prime \prime}$ & $112^{\circ} 14^{\prime} 27.6^{\prime \prime}$ & $4,794.37$ & 80 & $40-45$ \\
CNWR-P4a & 435611112142002 & $43^{\circ} 56^{\prime} 13.2^{\prime \prime}$ & $112^{\circ} 14^{\prime} 27.6^{\prime \prime}$ & $4,794.37$ & 80 & $72-77$ \\
\hline
\end{tabular}




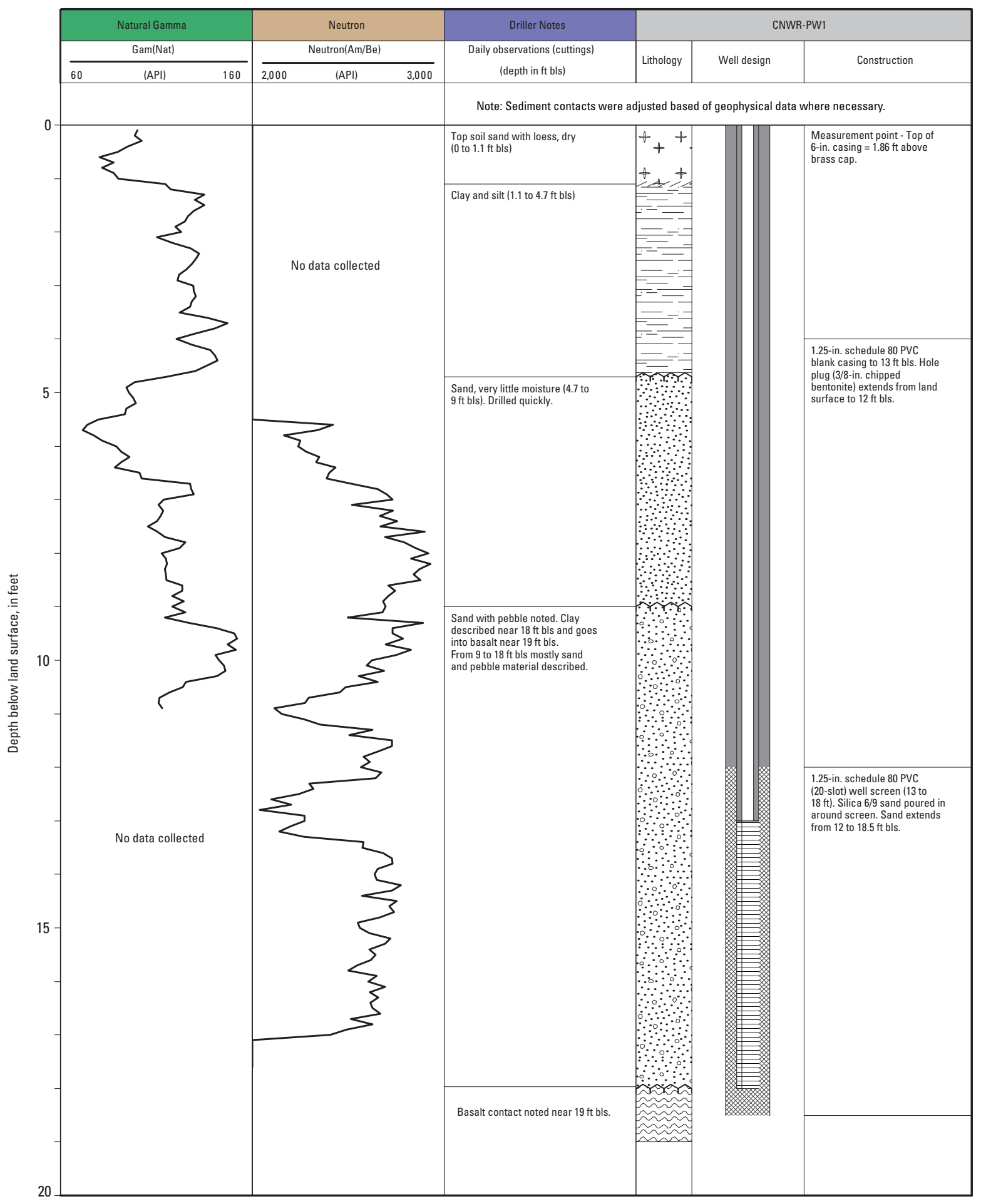

EXPLANATION

Definitions of terms

API - American

Petroleum Institute

bls - below land

surface

ft - feet

Gam(Nat) - natural

gamma radiation

in. - inch

Neutron - hydrogen

index

Am/Be - Americium/

Beryllium

Figure 2. Geophysical and construction logs run from total depth to land surface and lithologic logs described from drillers' notes and geophysical logs for monitoring well CNWR-PW1, Camas National Wildlife Refuge, eastern Idaho. 


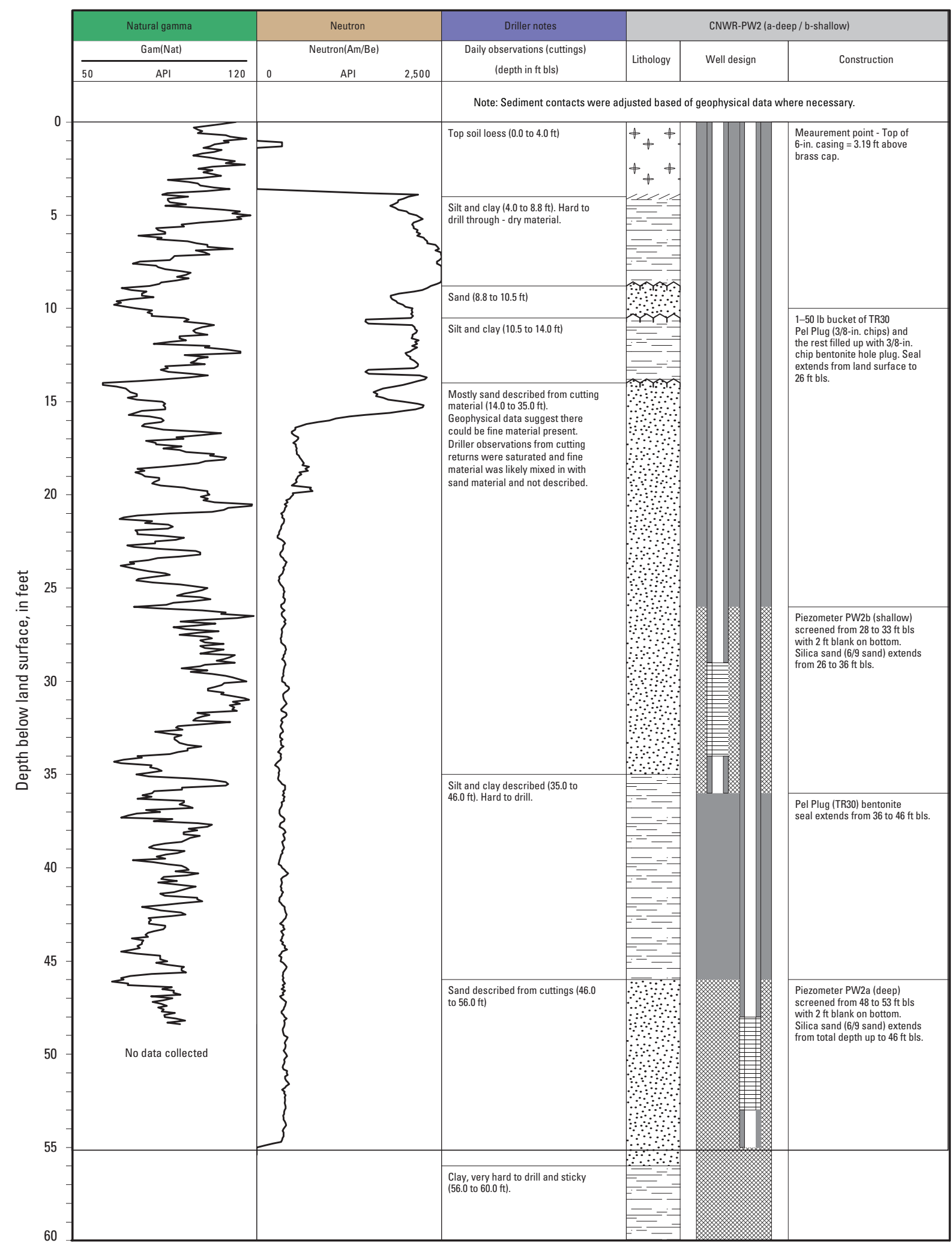

EXPLANATION

Definitions of terms

API - American

Petroleum Institute

bls - below land

surface

ft - feet

Gam(Nat) - natural

gamma radiation

in. - inch

Neutron - hydrogen

index

$\mathrm{Am} / \mathrm{Be}$ - Americium/

Beryllium

Figure 3. Geophysical and construction logs run from total depth to land surface and lithologic logs described from drillers' notes and geophysical logs for monitoring well CNWR-PW2, Camas National Wildlife Refuge, eastern Idaho. 


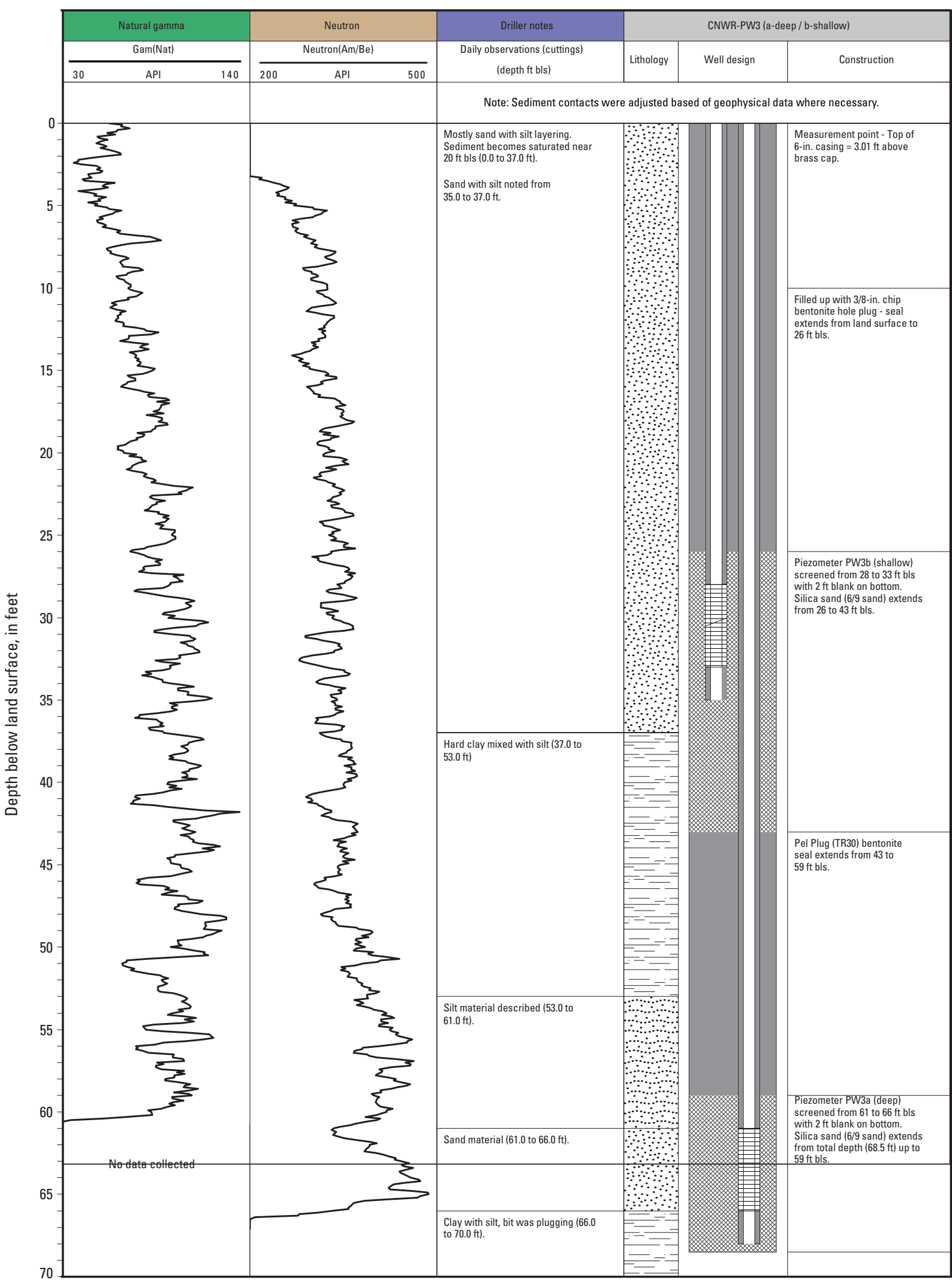

EXPLANATION

Definitions of terms

API - American

Petroleum Institute

bls - below land

surface

ft - feet

Gam(Nat) - natural

gamma radiation

in. - inch

Neutron - hydrogen

index

Am/Be - Americium/ Beryllium

Figure 4. Geophysical and construction logs run from total depth to land surface and lithologic logs described from drillers' notes and geophysical logs for monitoring well CNWR-PW3, Camas National Wildlife Refuge, eastern Idaho. 


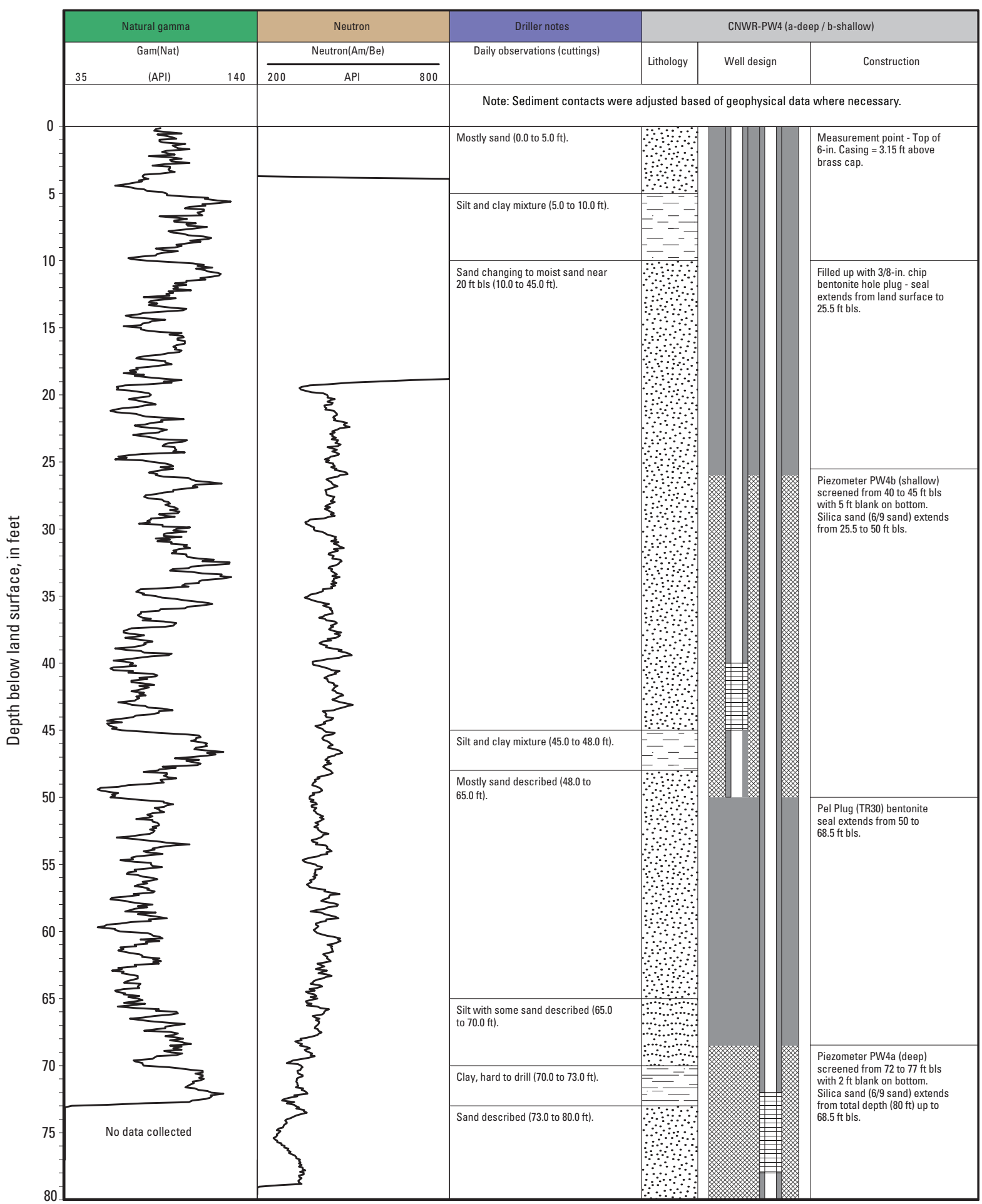

EXPLANATION

Definitions of terms

API - American

Petroleum Institute

bls - below land

surface

ft - feet

Gam(Nat) - natural gamma radiation

in. - inch

Neutron - hydrogen

index

Am/Be - Americium/

Beryllium

Figure 5. Geophysical and construction logs run from total depth to land surface and lithologic logs described from drillers' notes and geophysical logs for monitoring well CNWR-PW4, Camas National Wildlife Refuge, eastern Idaho. 


\section{Soil Probe Holes Drilled during Stage 2}

Seven soil probe coreholes were drilled into the dry bed sediment of four ponds or lakes at the Refuge (fig. 1). Two additional soil probe coreholes were planned for the eastern part of Sandhole Lake, but drilling was not possible due to standing water in this part of the lake.

Sediment coring was done using a Geoprobe ${ }^{\mathrm{TM}}$ DT66 direct-push rig in conjunction with a Geoprobe ${ }^{\mathrm{TM}}$ DT22 sampling system. The DT66 rig was used to drive probe rods through sediment until the first basalt contact or until soil probe sampling could not go deeper. Probe rods were driven down in 5-ft sections, and sediment was captured in 1.25-in. (31.8 mm) diameter plastic liners. The plastic liners were removed from the probe rods and labeled in the field. Some liners had complete samples (100 percent recovery), but other samples resulted in limited recovery ( $<30$ percent; table 2$)$. Attempts were made to collect continuous in-situ samples to best represent changes within the vertical sediment strata; however, recovery through consolidated clay and pebble layers was difficult in sections. Total depth to which sediment samples were collected ranged from 10.0 to $38.5 \mathrm{ft}$ bls.

Table 2. Location and percentage of recovery for soil probe holes, Camas National Wildlife Refuge, eastern Idaho.

[Soil probe site name: Local well identifier used in this study. Location of well is shown in figure 1. L ongitude and Latitude: Survey taken at soil probe location after drilling. Soil probe collection depth: Interval recovered in plastic liners. Length of soil recovered: Measured amount of sediment recovered in plastic liners used for sediment analysis. Material recovered for sieve analysis: Computed based on soil probe collection depth and length of soil recovered. Abbreviations: ft bls, feet below land surface; NAD 27, North American Datum of 1927]

\begin{tabular}{|c|c|c|c|c|c|}
\hline $\begin{array}{l}\text { Soil probe } \\
\text { site name }\end{array}$ & $\begin{array}{l}\text { Latitude } \\
\text { (NAD 27) }\end{array}$ & $\begin{array}{l}\text { Longitude } \\
\text { (NAD 27) }\end{array}$ & $\begin{array}{c}\text { Soil probe } \\
\text { collection depth } \\
\text { (ft bls) }\end{array}$ & $\begin{array}{l}\text { Length of } \\
\text { soil recovered } \\
\text { (ft) }\end{array}$ & $\begin{array}{l}\text { Material recovered } \\
\text { for sieve analysis } \\
\text { (percent) }\end{array}$ \\
\hline \multirow[t]{3}{*}{ BP1 } & $43^{\circ} 56^{\prime} 51.89^{\prime \prime}$ & $112^{\circ} 16^{\prime} 4.18^{\prime \prime}$ & $0.0-5.0$ & 3.3 & 66 \\
\hline & $43^{\circ} 56^{\prime} 51.89^{\prime \prime}$ & $112^{\circ} 16^{\prime} 4.18^{\prime \prime}$ & $5.0-8.5$ & 3.4 & 97 \\
\hline & $43^{\circ} 56^{\prime} 51.89^{\prime \prime}$ & $112^{\circ} 16^{\prime} 4.18^{\prime \prime}$ & $8.5-15.0$ & 4.7 & 63 \\
\hline \multirow[t]{6}{*}{ BP2 } & $43^{\circ} 56^{\prime} 54.23^{\prime \prime}$ & $112^{\circ} 16^{\prime} 12.26^{\prime \prime}$ & $0.0-5.0$ & 1.6 & 32 \\
\hline & $43^{\circ} 56^{\prime} 54.23^{\prime \prime}$ & $112^{\circ} 16^{\prime} 12.26^{\prime \prime}$ & $5.0-10.0$ & 4.3 & 86 \\
\hline & $43^{\circ} 56^{\prime} 54.23^{\prime \prime}$ & $112^{\circ} 16^{\prime} 12.26^{\prime \prime}$ & $10.0-15.0$ & 4.1 & 82 \\
\hline & $43^{\circ} 56^{\prime} 54.23^{\prime \prime}$ & $112^{\circ} 16^{\prime} 12.26^{\prime \prime}$ & $15.0-19.0$ & 2.4 & 60 \\
\hline & $43^{\circ} 56^{\prime} 54.23^{\prime \prime}$ & $112^{\circ} 16^{\prime} 12.26^{\prime \prime}$ & $19.0-20.0$ & 1.0 & 100 \\
\hline & $43^{\circ} 56^{\prime} 54.23^{\prime \prime}$ & $112^{\circ} 16^{\prime} 12.26^{\prime \prime}$ & $20.0-25.0$ & 4.4 & 88 \\
\hline \multirow[t]{4}{*}{ TO1 } & $43^{\circ} 55^{\prime} 55.49^{\prime \prime}$ & $112^{\circ} 16^{\prime} 26.73^{\prime \prime}$ & $0.0-5.0$ & 1.3 & 26 \\
\hline & $43^{\circ} 55^{\prime} 55.49^{\prime \prime}$ & $112^{\circ} 16^{\prime} 26.73^{\prime \prime}$ & $5.0-10.0$ & 4.2 & 84 \\
\hline & $43^{\circ} 55^{\prime} 55.49^{\prime \prime}$ & $112^{\circ} 16^{\prime} 26.73^{\prime \prime}$ & $10.0-15.0$ & 1.5 & 30 \\
\hline & $43^{\circ} 55^{\prime} 55.49^{\prime \prime}$ & $112^{\circ} 16^{\prime} 26.73^{\prime \prime}$ & $15.0-20.0$ & 5.0 & 100 \\
\hline \multirow[t]{4}{*}{ TO2 } & $43^{\circ} 55^{\prime} 35.82^{\prime \prime}$ & $112^{\circ} 16^{\prime} 25.73^{\prime \prime}$ & $0.0-5.0$ & 3.1 & 62 \\
\hline & $43^{\circ} 55^{\prime} 35.82^{\prime \prime}$ & $112^{\circ} 16^{\prime} 25.73^{\prime \prime}$ & $5.0-10.0$ & 3.1 & 62 \\
\hline & $43^{\circ} 55^{\prime} 35.82^{\prime \prime}$ & $112^{\circ} 16^{\prime} 25.73^{\prime \prime}$ & $10.0-14.0$ & 4.0 & 100 \\
\hline & $43^{\circ} 55^{\prime} 35.82^{\prime \prime}$ & $112^{\circ} 16^{\prime} 25.73^{\prime \prime}$ & $14.0-15.0$ & 1.0 & 100 \\
\hline \multirow[t]{5}{*}{ TW1 } & $43^{\circ} 55^{\prime} 58.52^{\prime \prime}$ & $112^{\circ} 15^{\prime} 39.34^{\prime \prime}$ & $0.0-5.0$ & 2.5 & 50 \\
\hline & $43^{\circ} 55^{\prime} 58.52^{\prime \prime}$ & $112^{\circ} 15^{\prime} 39.34^{\prime \prime}$ & $5.0-10.0$ & 5.0 & 100 \\
\hline & $43^{\circ} 55^{\prime} 58.52^{\prime \prime}$ & $112^{\circ} 15^{\prime} 39.34^{\prime \prime}$ & $10.0-12.5$ & 2.4 & 96 \\
\hline & $43^{\circ} 55^{\prime} 58.52^{\prime \prime}$ & $112^{\circ} 15^{\prime} 39.34^{\prime \prime}$ & $12.5-15.0$ & 2.5 & 100 \\
\hline & $43^{\circ} 55^{\prime} 58.52^{\prime \prime}$ & $112^{\circ} 15^{\prime} 39.34^{\prime \prime}$ & $15.0-18.0$ & 3.0 & 100 \\
\hline \multirow[t]{8}{*}{ TW2 } & $43^{\circ} 55^{\prime} 43.64^{\prime \prime}$ & $112^{\circ} 15^{\prime} 58.69^{\prime \prime}$ & $0.0-5.0$ & 1.5 & 30 \\
\hline & $43^{\circ} 55^{\prime} 43.64^{\prime \prime}$ & $112^{\circ} 15^{\prime} 58.69^{\prime \prime}$ & $5.0-10.0$ & 5.0 & 100 \\
\hline & $43^{\circ} 55^{\prime} 43.64^{\prime \prime}$ & $112^{\circ} 15^{\prime} 58.69^{\prime \prime}$ & $10.0-15.0$ & 3.9 & 78 \\
\hline & $43^{\circ} 55^{\prime} 43.64^{\prime \prime}$ & $112^{\circ} 15^{\prime} 58.69^{\prime \prime}$ & $15.0-20.0$ & 3.9 & 78 \\
\hline & $43^{\circ} 55^{\prime} 43.64^{\prime \prime}$ & $112^{\circ} 15^{\prime} 58.69^{\prime \prime}$ & $20.0-25.0$ & 4.7 & 94 \\
\hline & $43^{\circ} 55^{\prime} 43.64^{\prime \prime}$ & $112^{\circ} 15^{\prime} 58.69^{\prime \prime}$ & $25.0-30.0$ & 3.4 & 68 \\
\hline & $43^{\circ} 55^{\prime} 43.64^{\prime \prime}$ & $112^{\circ} 15^{\prime} 58.69^{\prime \prime}$ & $30.0-35.0$ & 5.0 & 100 \\
\hline & $43^{\circ} 55^{\prime} 43.64^{\prime \prime}$ & $112^{\circ} 15^{\prime} 58.69^{\prime \prime}$ & $35.0-38.5$ & 3.5 & 100 \\
\hline \multirow[t]{3}{*}{ SH1 } & $43^{\circ} 55^{\prime} 56.23^{\prime \prime}$ & $112^{\circ} 14^{\prime} 23.82^{\prime \prime}$ & $0.0-5.0$ & 2.0 & 40 \\
\hline & $43^{\circ} 55^{\prime} 56.23^{\prime \prime}$ & $112^{\circ} 14^{\prime} 23.82^{\prime \prime}$ & $5.0-7.5$ & 1.9 & 76 \\
\hline & $43^{\circ} 55^{\prime} 56.23^{\prime \prime}$ & $112^{\circ} 14^{\prime} 23.82^{\prime \prime}$ & $7.5-10.0$ & 2.5 & 100 \\
\hline
\end{tabular}


Sediment sample locations and percentage of material recovered are identified in table 2. After drilling sediment cores to completion depth, probe holes were backfilled with bentonite chips and abandoned.

\section{Geophysical Data}

Wireline geophysical logs, consisting of natural gamma and neutron measurements, were collected after completion of drilling at each of the four auger hole locations. No logs were collected for soil probe locations due to the limited inner-diameter of the piping used for soil probe collection. Geophysical data were collected using Century Geophysical Corporation $^{\mathrm{TM}}$ logging equipment, and the resulting data files were processed using WellCAD ${ }^{\mathrm{TM}}$ analytical software. Geophysical log data were collected and saved as electronic files in the form of physical measurement and depth at $0.2-\mathrm{ft}$ depth intervals. The USGS INL Project Office currently archives wireline geophysical data through the "USGS Log Archiver" database (http://logarchiver.usgs.gov/, U.S. Geological Survey, 2011). The Web site lists current USGS policies for storage and retrieval of geophysical log information. Logs also are available upon request of the USGS INL Project Office.

\section{Natural Gamma Logs}

Natural gamma logs record gamma radiation emitted by naturally occurring radioisotopes, and the natural gamma detector measures total gamma radiation without distinguishing between individual contributions of the various isotopes. For this study, natural gamma logs were used to refine interpretations of sediment layering and contact locations determined from drillers' notes. Generally, high natural gamma reflects finer grained material, whereas low natural gamma reflects sediment material considered more coarse. Based on visual inspection, natural gamma measurements appear to be slightly affected by the size and drilling technique used during this investigation, where the hole diameter was about 8-in. and the auger method forms a mud cake along the wall of the drilled hole under saturated conditions.

\section{Neutron Logs}

Neutron measurements are a general indicator of changes in hydrogen content, where measurements are directly affected by areas storing water and (or) areas that do not store water. The neutron log records the continuous measurement of the induced radiation produced by bombarding surrounding media (casing, formation, and fluid) with fast neutrons (energies greater than $10^{5}$ electronvolts $[\mathrm{eV}]$ ) from a sealed neutron source, which collide with surrounding atomic nuclei until they are captured (Keys, 1990, section 5, p. 95).
The neutron tool has an americium/beryllium neutron source and a helium-3 detector that counts slow (thermal) neutrons (those that have energies less than $0.025 \mathrm{eV}$ ). Based on visual inspection, neutron measurements also appear to be slightly affected by the size and drilling technique used during this investigation.

\section{Sediment Analysis of Soil Probe Cores}

The seven soil probe cores collected with the Geoprobe ${ }^{\mathrm{TM}}$ DT66 underwent grain-size analysis at the USGS Core Library located in the Central Facilities Area at the Idaho National Laboratory. Soil probe core samples were removed from plastic liners, then divided into 49 subsamples (hereafter referred to as "samples") based on visual inspection. Samples were allowed to open-air dry for about 10 days before starting particle-size analysis (fig. 6A). Samples with residual moisture could not be easily sieved, therefore it was important to allow sufficient time to dry the samples.

The samples were analyzed using a dry-sieve technique (American Society of Civil Engineers, 1975; American Society for Testing and Materials, 1985). Sieve sizes ranged from greater than or equal to $4 \mathrm{~mm}$ to less than or equal to 0.0625 and sediment particles were partitioned into eight size classifications, ranging from pebble ( $\geq 4 \mathrm{~mm})$, very coarse to very fine sand ( $<4$ to $\geq 0.0625 \mathrm{~mm}$ ), to silt and (or) clay $(<0.0625 \mathrm{~mm})$ (appendix A). The sand size classification included six classes: very coarse sand, granule, coarse sand, medium sand, fine sand, and very fine sand. Because of the size constraints of the plastic liners used for recovery, particles larger than $4 \mathrm{~mm}$ were grouped into the pebble class-size classification. No attempts were made to classify particles larger than pebble size classification.

After air-drying (fig. 6A), the samples were weighed and the net sample weight was reported prior to sieving (appendix A). After the net sample weight was reported, each sample was run through a series of sieves, largest to smallest, using a mechanical shaker (fig. 6B) operated for about 10 minutes (American Society of Civil Engineers, 1975, p. 412). Afterwards, each sieve containing sediment was separated and weight reported based on sieve size (fig. 6C and 6D; table 3). Particles less than $0.0625 \mathrm{~mm}$ were collected in a closed sieve pan at the bottom of the sieve stack and weighed. Sieve testing results were entered into a pre-programmed spreadsheet to calculate the following: (1) calculate the percent-finer-than fraction, cumulated percent-finer-than fraction, and the characteristic particle size, and (2) graph the cumulative percent-finer-than fraction and the distribution of the sediment sizes. Sieve analysis results for each soil probe sub-sample are presented in appendix A. Once sediment particles were sieved and weighed, sediment particle characteristics were subdivided into six classes, based on percent finer, along with sample standard deviation. 


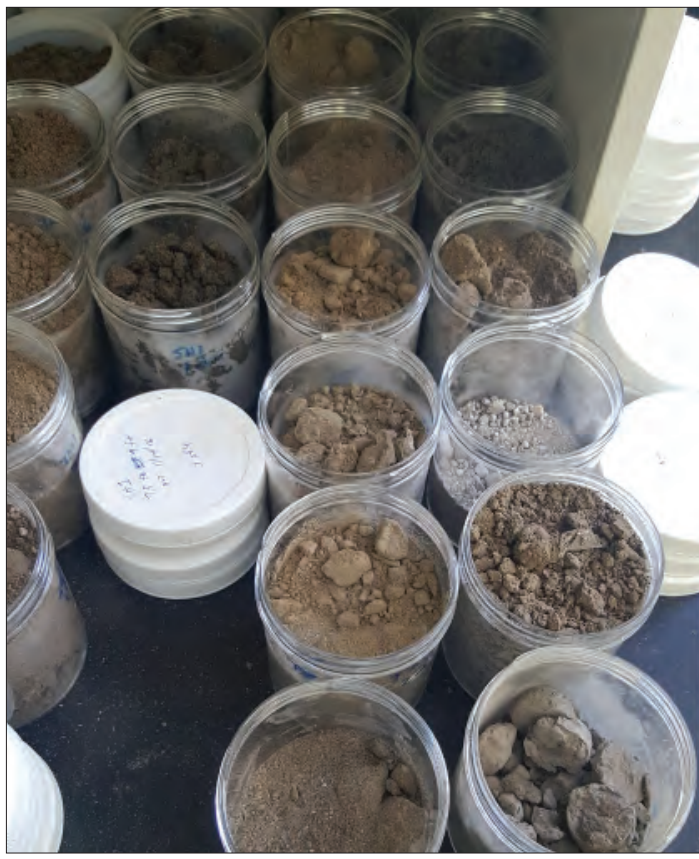

A. Separating and drying samples for sieving.

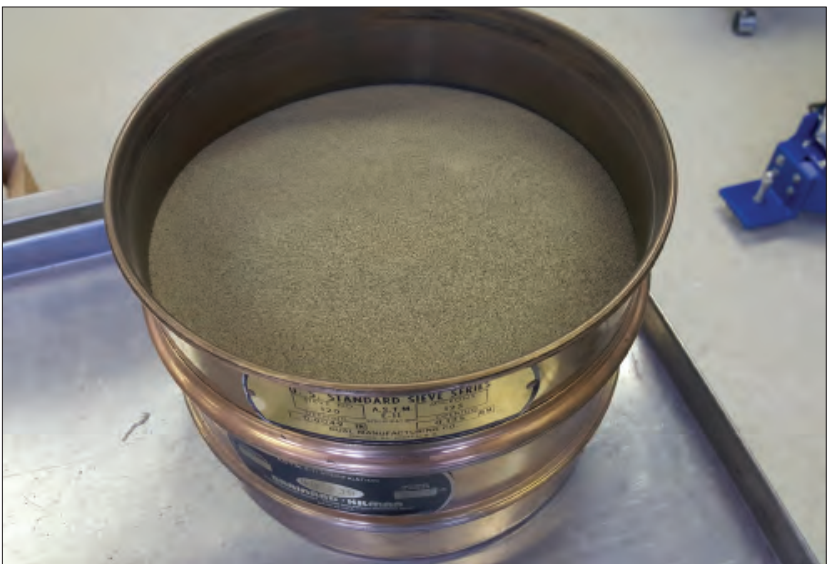

C. Separating the samples after sieving.

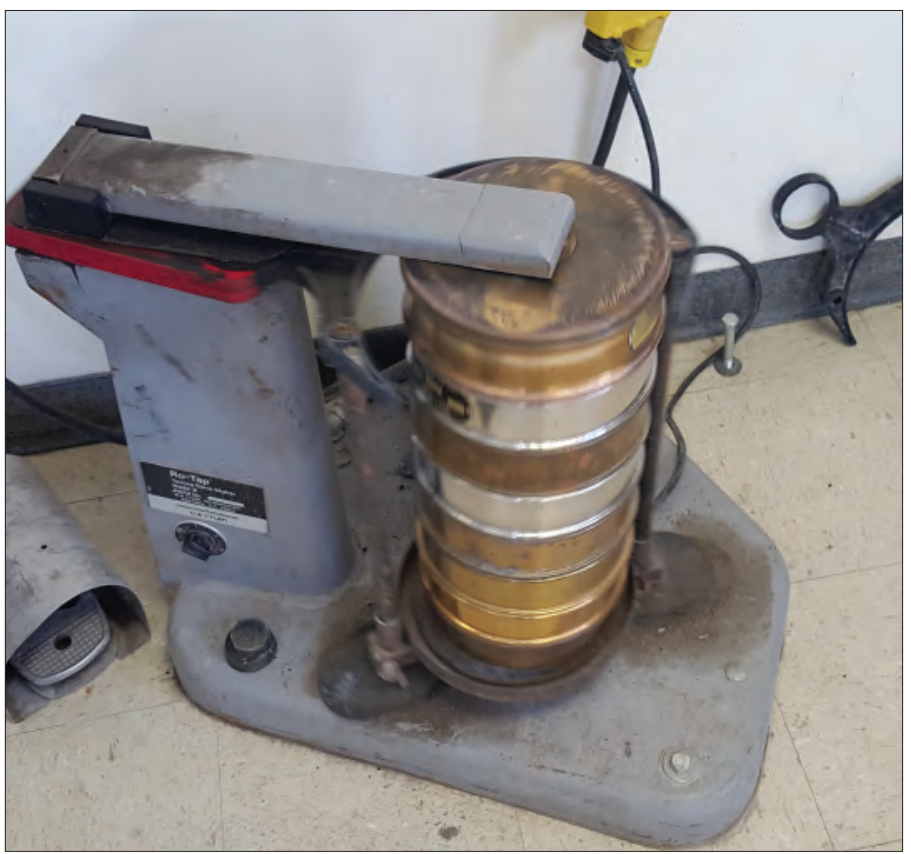

B. Sieving the samples using a mechanical shaker.

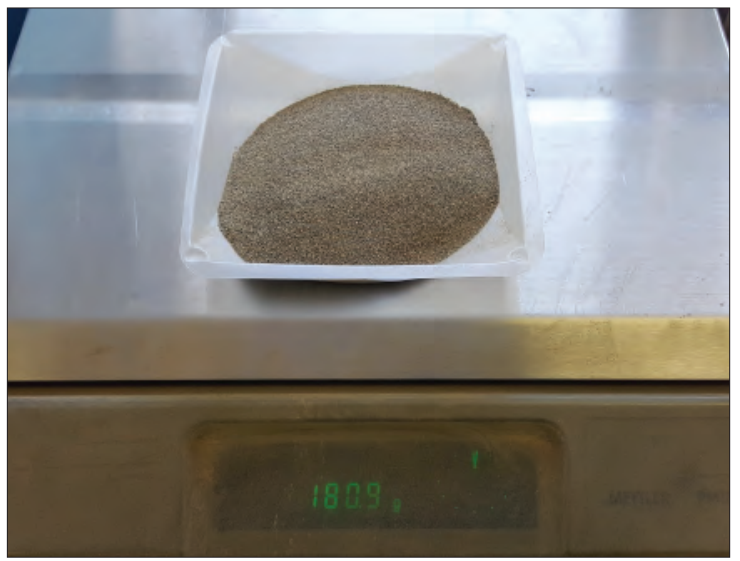

D. Recording the weight of each sample.

Figure 6. Soil probes and samples prepared for particle-size analysis, Camas National Wildlife Refuge, eastern Idaho. 
Table 3. Particle-size characteristics from particle grain-size analysis of sediment samples from soil probe sites and classification used for soil probe analysis, Camas National Wildlife Refuge, eastern Idaho.

[Soil probe site name: Local well identifier used in this study. Location of sampling sites shown in figure 1. R, run number (example R1 = run 1). Sample depth: The interval where the sample was collected during soil probe drilling. Particle-size data shown in appendix A. Particle-size diameter: The letter $\mathrm{d}$ with the numerical subscript denotes the particle-size diameter of the sample for which the percentage by count is finer than the designated diameter size. For example, $d_{65}=0.45 \mathrm{~mm}$ indicates that 65 percent of the sediment by weight is finer than $0.45 \mathrm{~mm}$. Hydraulic conductivity: Computed values from average particle size $\left(\mathrm{d}_{50}\right)$, shape factor, and exponent factor (eq. 1). Abbreviations: $\mathrm{ft}$ bls, feet below land service; $\mathrm{ft} / \mathrm{d}$, feet per day; mm, millimeter; -, no data]

\begin{tabular}{|c|c|c|c|c|c|c|c|c|c|}
\hline \multirow{2}{*}{$\begin{array}{l}\text { Soil probe } \\
\text { site name }\end{array}$} & \multirow{2}{*}{$\begin{array}{c}\text { Sample depth } \\
\text { (ft bls) }\end{array}$} & \multicolumn{6}{|c|}{ Particle-size diameter (mm) } & \multirow{2}{*}{$\begin{array}{l}\text { Geometric standard } \\
\text { deviation } \\
(\mathrm{mm})\end{array}$} & \multirow{2}{*}{$\begin{array}{c}\text { Hydraulic } \\
\text { conductivit } \\
\text { (ft/d) }\end{array}$} \\
\hline & & $d_{15.9}$ & $d_{35}$ & $d_{50}$ & $d_{65}$ & $d_{84.1}$ & $d_{90}$ & & \\
\hline BP1-R1 & $0.0-2.0$ & 0.13 & 0.26 & 0.46 & 1.00 & 2.02 & 2.61 & 3.94 & 125 \\
\hline BP1-R2 & $2.0-5.0$ & 0.16 & 0.28 & 0.38 & 0.61 & 2.08 & 3.26 & 3.61 & 91 \\
\hline BP1-R3 & 5.0-8.5 & 0.15 & 0.25 & 0.38 & 0.73 & 2.98 & 4.12 & 4.46 & 91 \\
\hline BP1-R4 & 8.5-11.0 & 0.26 & 0.42 & 0.66 & 1.31 & 4.40 & 5.49 & 4.11 & 227 \\
\hline BP1-R5 & $11.0-15.0$ & 0.18 & 0.29 & 0.37 & 0.47 & 1.47 & 2.93 & 2.86 & 87 \\
\hline BP2-R1 & $0.0-5.0$ & 0.13 & 0.24 & 0.35 & 0.50 & 1.91 & 3.08 & 3.83 & 80 \\
\hline BP2-R2 & $5.0-8.0$ & 0.16 & 0.27 & 0.40 & 0.75 & 2.69 & 4.22 & 4.10 & 99 \\
\hline BP2-R3 & 8.0-10.0 & 0.19 & 0.37 & 0.62 & 1.57 & 4.19 & 5.33 & 4.70 & 204 \\
\hline BP2-R4 & $10.0-15.0$ & 0.18 & 0.32 & 0.46 & 0.93 & 3.04 & 4.36 & 4.11 & 125 \\
\hline BP2-R5 & $15.0-17.0$ & 0.18 & 0.31 & 0.42 & 0.64 & 1.65 & 2.59 & 3.03 & 108 \\
\hline BP2-R6 & $17.0-20.0$ & 0.27 & 0.41 & 0.61 & 0.98 & 2.00 & 2.96 & 2.72 & 199 \\
\hline BP2-R7 & $20.0-22.0$ & 0.21 & 0.30 & 0.35 & 0.42 & 0.61 & 0.94 & 1.70 & 80 \\
\hline BP2-R8 & $22.0-24.0$ & 0.28 & 0.45 & 0.74 & 1.64 & 4.94 & 5.91 & 4.20 & 274 \\
\hline BP2-R9 & $24.0-25.0$ & - & - & - & - & - & - & - & - \\
\hline TO1-R1 & $0.0-5.0$ & 0.09 & 0.18 & 0.26 & 0.40 & 1.66 & 2.85 & 4.20 & 49 \\
\hline TO1-R2 & $5.0-7.5$ & 0.08 & 0.15 & 0.23 & 0.45 & 1.60 & 2.39 & 4.62 & 40 \\
\hline TO1-R3 & 7.5-9.0 & 0.09 & 0.18 & 0.33 & 0.85 & 1.98 & 2.86 & 4.61 & 72 \\
\hline TO1-R4 & $9.0-10.0$ & 0.21 & 0.43 & 0.74 & 1.53 & 4.10 & 5.26 & 4.42 & 274 \\
\hline TO1-R5 & $10.0-15.0$ & 0.11 & 0.25 & 0.50 & 1.13 & 2.50 & 3.42 & 4.77 & 143 \\
\hline TO1-R6 & $15.0-16.5$ & 0.12 & 0.26 & 0.39 & 0.64 & 1.88 & 2.91 & 3.96 & 95 \\
\hline TO1-R7 & $16.5-18.0$ & 0.14 & 0.20 & 0.27 & 0.34 & 0.45 & 0.49 & 1.79 & 52 \\
\hline TO1-R8 & $18.0-20.0$ & 0.20 & 0.30 & 0.37 & 0.45 & 0.95 & 3.21 & 2.18 & 87 \\
\hline TO2-R1 & $0.0-2.5$ & 0.11 & 0.18 & 0.24 & 0.34 & 0.71 & 1.32 & 2.54 & 43 \\
\hline TO2-R2 & $2.5-5.0$ & 0.07 & 0.12 & 0.16 & 0.21 & 0.36 & 0.45 & 2.22 & 22 \\
\hline TO2-R3 & 5.0-7.5 & 0.06 & 0.14 & 0.27 & 0.71 & 1.74 & 2.32 & 5.26 & 52 \\
\hline TO2-R4 & $7.5-10.0$ & 0.09 & 0.18 & 0.40 & 0.83 & 2.26 & 3.14 & 5.13 & 99 \\
\hline TO2-R5 & $10.0-12.0$ & 0.14 & 0.23 & 0.32 & 0.45 & 1.52 & 2.37 & 3.30 & 69 \\
\hline TO2-R6 & $12.0-14.0$ & 0.14 & 0.22 & 0.29 & 0.36 & 0.49 & 0.71 & 1.87 & 58 \\
\hline TO2-R7 & $14.0-15.0$ & 0.11 & 0.22 & 0.34 & 0.56 & 2.29 & 3.36 & 4.56 & 76 \\
\hline TW1-R1 & $0.0-5.0$ & 0.08 & 0.14 & 0.17 & 0.22 & 0.34 & 0.41 & 2.02 & 24 \\
\hline TW1-R2 & $5.0-7.5$ & 0.09 & 0.15 & 0.19 & 0.26 & 0.64 & 1.21 & 2.71 & 29 \\
\hline TW1-R3 & $7.5-10.0$ & 0.13 & 0.15 & 0.18 & 0.20 & 0.25 & 0.31 & 1.39 & 27 \\
\hline TW1-R4 & $10.0-12.5$ & 0.09 & 0.14 & 0.18 & 0.24 & 0.40 & 0.47 & 2.12 & 27 \\
\hline TW1-R5 & $12.5-15.0$ & 0.13 & 0.20 & 0.27 & 0.34 & 0.46 & 0.52 & 1.88 & 52 \\
\hline TW1-R6 & $15.0-18.0$ & 0.22 & 0.36 & 0.49 & 1.60 & 4.66 & 5.70 & 4.60 & 139 \\
\hline TW2-R1 & $0.0-5.0$ & 0.08 & 0.15 & 0.21 & 0.33 & 1.16 & 1.95 & 3.83 & 34 \\
\hline TW2-R2 & $5.0-7.5$ & 0.09 & 0.14 & 0.19 & 0.25 & 0.44 & 0.57 & 2.24 & 29 \\
\hline TW2-R3 & 7.5-11.0 & 0.12 & 0.17 & 0.21 & 0.28 & 0.41 & 0.47 & 1.85 & 34 \\
\hline TW2-R4 & $11.0-15.0$ & 0.16 & 0.27 & 0.34 & 0.41 & 0.63 & 0.82 & 1.98 & 76 \\
\hline TW2-R5 & $15.0-20.0$ & 0.21 & 0.31 & 0.40 & 0.50 & 1.93 & 3.67 & 3.03 & 99 \\
\hline TW2-R6 & $20.0-25.0$ & 0.19 & 0.34 & 0.46 & 0.91 & 3.43 & 4.74 & 4.25 & 125 \\
\hline TW2-R7 & $25.0-30.0$ & 0.25 & 0.44 & 0.77 & 1.37 & 2.97 & 3.92 & 3.45 & 292 \\
\hline TW2-R8 & $30.0-33.0$ & 0.14 & 0.18 & 0.23 & 0.29 & 0.42 & 0.47 & 1.73 & 40 \\
\hline TW2-R9 & $33.0-35.0$ & 0.15 & 0.22 & 0.29 & 0.40 & 0.88 & 1.72 & 2.42 & 58 \\
\hline TW2-R10 & $35.0-38.5$ & 0.16 & 0.24 & 0.31 & 0.39 & 0.64 & 0.95 & 2.00 & 65 \\
\hline SH1-R1 & $0.0-5.0$ & 0.30 & 0.41 & 0.52 & 0.67 & 0.93 & 1.43 & 1.76 & 153 \\
\hline SH1-R2 & $5.0-7.5$ & 0.26 & 0.32 & 0.38 & 0.45 & 0.82 & 1.35 & 1.78 & 91 \\
\hline SH1-R3 & 7.5-9.0 & 0.17 & 0.25 & 0.31 & 0.37 & 0.48 & 0.64 & 1.68 & 65 \\
\hline SH1-R4 & $9.0-10.0$ & 0.15 & 0.22 & 0.29 & 0.40 & 0.86 & 1.90 & 2.39 & 58 \\
\hline
\end{tabular}




\section{Hydraulic Conductivity}

The hydraulic conductivities of sediment from soil probe samples were estimated from average sediment particle sizes determined from particle grain-size analysis. This method uses the average grain size $\left(d_{50}\right)$ and assumed textural maturity of sediment to approximate hydraulic conductivity (Shepherd, 1989; Fetter, 1994). The equation used to compute hydraulic conductivity is:

$$
K=C\left(d_{50}\right)^{j}
$$

where

$$
\begin{array}{cl}
K & \text { is the hydraulic conductivity, in feet per day, } \\
C & \text { is a shape factor-dimensionless constant, } \\
j & \text { is an exponent factor, and } \\
d_{50} & \text { is the average grain size (table 3). }
\end{array}
$$

\section{Groundwater Levels and Temperatures}

Seven In-Situ ${ }^{\circledR}$, Inc., Level Troll ${ }^{\circledR} 500$ data loggers were used to collect water-level and temperature measurements from monitoring wells. The data loggers came precalibrated from In-Situ ${ }^{\circledR}$, Inc., and verification tests of the accuracy of the water-level and temperature measurements were performed by the USGS Hydrologic Instrumentation Facility before use (Mark Carnley, U.S. Geological Survey, written commun., July 2016). The accuracy of the water-level and temperature measurements was $\pm 0.0345 \mathrm{ft}$ and $\pm 0.1^{\circ} \mathrm{C}$, respectively (https://in-situ.com/wp-content/uploads/2014/11/ Level TROLL 400-500-700-Baro Specification Sheet.pdf). Additionally, periodic field visits every $2-3$ months were made to inspect the data loggers, verify that the data loggers were operating correctly, retrieve data, and to calibrate water-level measurements from the data loggers with water-level measurements made with electric tapes. Specific calibration and data collection procedures for data loggers and electric tapes presented in Bartholomay and others (2014) were followed in this study.

\section{Characterization of Sediment}

\section{Geophysical Logs}

Geophysical logs provided a complete and continuous formation representation adjacent to the well bore. However, drill casing diameter and drilling method need to be considered when looking at geophysical data through auger flights. Auger drilling returns sediment material to the surface as the auger flights are spun into the ground, and saturated sediment can result in sluffing and unstable hole conditions. Additionally, some sediment can collect on the walls of the drilled hole and could affect the geophysical signature collected. Thus, during auger drilling, sediment particle sizes can be difficult to determine from material returns without continuous sediment sampling.

Changes in sediment lithology were evaluated using both drillers' notes and geophysical log data collected during and after drilling was completed. A synergistic approach was used with the data collected to approximate where changes in sediment layering occurred. This synergistic approach provided for a better interpretation of lithology than the drillers' notes or the geophysical logs provided separately. The drillers' notes generally were used to estimate sediment class size based on returns that came to the surface, whereas natural gamma logs were used to pick out subtle changes in sediment layering. The sediment classes included clay/silt, sand, and pebble size material; the sediment class for sand was not broken down into finer sand classes because material returns during drilling often were mixed with water, forming a slurry. Composites of natural gamma and neutron measurements, drillers' notes, and general lithology are displayed in figures $2-5$.

\section{Description of Sediment from Monitoring Wells}

Depth to sediment unit and type was estimated for sediment unearthed while drilling the monitoring wells. Some uncertainty can be assumed with sediment descriptions using this method, because subtle changes in sediment layering and changes in sand particle size could not always be captured, so these estimates were coarse and sometimes inconsistencies between drillers' notes and geophysical logs could not be reconciled.

\section{CNWR-PW1}

Monitoring well CNWR-PW1 is located along the northern edge of Redhead Pond and was drilled to a depth of $19 \mathrm{ft}$, where basalt was found (fig. 1, table 1). Sediment particle size ranged from clay/silt to pebble (fig. 2). Clay/silt was present to a depth of about $4.7 \mathrm{ft}$ bls; below, the material changes to a sand, grading to a sand with pebble material near $9 \mathrm{ft}$ bls. The sediment below $9 \mathrm{ft}$ bls was described as sand and pebble material. Toward the bottom of CNWR-PW1 clay/silt were noted just above the basalt interface (fig. 2).

\section{CNWR-PW2}

Monitoring well CNWR-PW2 is located between Toomey Pond and Two-way Pond and was drilled to a depth of $60 \mathrm{ft}$ (fig. 1, table 1). Sediment particle size ranged from clay/silt to sand (fig. 3). Clay/silt was present to a depth of about $8.8 \mathrm{ft}$ bls and then graded back and forth between sand and clay/silt along the entire monitor well section drilled. Sand appears to be layered between silt/clay layers (fig. 3). Toward the bottom of CNWR-PW2 the sediment material was clay and hard to drill, preventing reaching the first basalt contact. 


\section{CNWR-PW3}

Monitoring well CNWR-PW3 is located near a northern finger off Rays Lake and was drilled to a depth of $69 \mathrm{ft}$ (fig. 1, table 1). Sediment particle size ranged from clay/silt to sand (fig. 4). Sand with silt was present to a depth of about $37 \mathrm{ft}$ bls, and the sand and silt layers could not be differentiated (fig. 4). A hard clay and silt layer was encountered near $37 \mathrm{ft} \mathrm{bls} \mathrm{and}$ extends down to about $53 \mathrm{ft}$ bls (fig. 4). Toward the bottom of CNWR-PW3, the sediment material was clay with silt and hard to drill, which prevented drilling any further.

\section{CNWR-PW4}

Monitoring well CNWR-PW4 is located near the northern finger of Sandhole Lake and was drilled to a depth of $80 \mathrm{ft}$ bls (fig. 1, table 1). Sediment particle size ranged from clay/silt to sand (fig. 5). Sand was present to a depth of about $5 \mathrm{ft}$ bls, and the sand grades to clay/silt from 5 to $10 \mathrm{ft}$ bls (fig. 5). Sand (ranging in grain size) was the most prominent sediment material, with only thin layers of clay/silt.

\section{Description of Sediment Collected from Soil Probe Cores}

\section{Big Pond Soil Probes}

The two soil probe sites within Big Pond include Big Pond site 1 (BP1) and Big Pond site 2 (BP2) and were drilled to depths of 15 and $25 \mathrm{ft}$ bls, respectively (fig. 1, table 2). Sediment recovery for soil probe site BP1 ranged between 63 and 97 percent and the total combined recovery for all samples was about 76 percent based on samples recovered in three plastic liners (table 2). Sediment recovery for soil probe site BP2 ranged between 32 and 100 percent and the total combined recovery for all samples was about 71 percent based on samples recovered from six plastic liners (table 2). No description was made for missing and (or) not recovered sediment material from these or other coreholes.

Soil probe site BP1 is located along the western edge of Big Pond (fig. 1). Based on grain-size analysis from the five samples collected from plastic liners, particles ranged from clay/silt to pebble (appendix A). The $\mathrm{d}_{50}$ for the samples ranged from 0.37 to $0.66 \mathrm{~mm}$, indicating that the average grain size was medium to coarse sand (fig. 7, table 3, appendix A).

Soil probe site BP2 is located along the eastern edge of Big Pond (fig. 1). Based on grain-size analysis from nine samples collected from plastic liners, particles ranged from clay/silt to pebble (table 3, appendix A). Particle-size analysis was not done on the deepest sample, collected between 24 and $25 \mathrm{ft}$ bls, because this sample consisted of sediment and basalt rock fragments at the sediment-basalt interface. The remaining eight samples displayed a $\mathrm{d}_{50}$ ranging from 0.35 to $0.74 \mathrm{~mm}$, indicating that the average grain size was medium to coarse sand (fig. 7, table 3, appendix A).
Sediment samples analyzed from sites BP1 and BP2 showed consistent $\mathrm{d}_{50}$ values at both soil probe locations. The predominant sediment particle size was a medium to coarse sand. Big Pond soil probe samples indicated limited amounts of clay/silt and (or) very fine sand.

\section{Toomey Soil Probes}

The two soil probe sites within Toomey Pond include Toomey site 1 (TO1) and Toomey site 2 (TO2), and were drilled to depths of 20 and $15 \mathrm{ft}$, respectively (fig. 1, table 2). Sediment recovery for soil probe site TO1 ranged between 26 and 100 and the total combined recovery for all samples was about 60 percent, based on samples recovered in four plastic liners (table 2). Sediment recovery for soil probe site TO2 ranged between 62 and 100 percent and the total combined recovery was about 75 percent, based on samples recovered from four plastic liners (table 2).

Soil probe site TO1 is located along the central and western edge of Toomey Pond in close proximity to Camas Creek (fig. 1). Based on grain-size analysis from the eight samples collected from plastic liners, sediment particles ranged from clay/silt to pebble (appendix A). The $\mathrm{d}_{50}$ ranged from 0.23 to $0.74 \mathrm{~mm}$, indicating that the average grain size was fine to coarse sand (table 3 ). Based on the $\mathrm{d}_{50}$ values, medium and fine sand were recovered in the upper $9 \mathrm{ft}$; however, from 9 to $15 \mathrm{ft}$ bls the material grades to coarse sand and grades back to medium sand between 15 and $20 \mathrm{ft}$ bls.

Soil probe site TO2 is located along the southern end of Toomey Pond (fig. 1). Based on grain-size analysis from seven samples collected from plastic liners, particles ranged from clay/silt to pebble (appendix A). The $\mathrm{d}_{50}$ ranged from 0.16 to $0.40 \mathrm{~mm}$, indicating that the average grain size was fine to medium sand (fig. 7; table 3). The upper $5 \mathrm{ft}$ of TO2 was a fine sand; however, from 5 to $15 \mathrm{ft}$ the material grades to medium sand.

Sample analysis from soil probe sites TO1 and TO2 show similar $d_{50}$ values from the south to north ends of Toomey Pond. Based on $\mathrm{d}_{50}$, sediment particle sizes for Toomey Pond were generally fine and medium sand at both locations, with some coarse sand in soil probe site TO1.

\section{Two-Way Pond Soil Probes}

The two soil probe sites within Two-way Pond include Two-way Pond site 1 (TW1) and Two-way Pond site 2 (TO2) and were drilled to depths of 18 and $38.5 \mathrm{ft}$, respectively (fig. 1, table 2). Sediment recovery for soil probe site TW1 ranged between 50 and 100 percent and total combined recovery for all samples was about 86 percent based on samples recovered from five plastic liners. Sediment recovery for soil probe site TW2 ranged between 30 and 100 percent and the total combined recovery for all samples was about 80 percent based on samples recovered in eight plastic liners (table 2). 


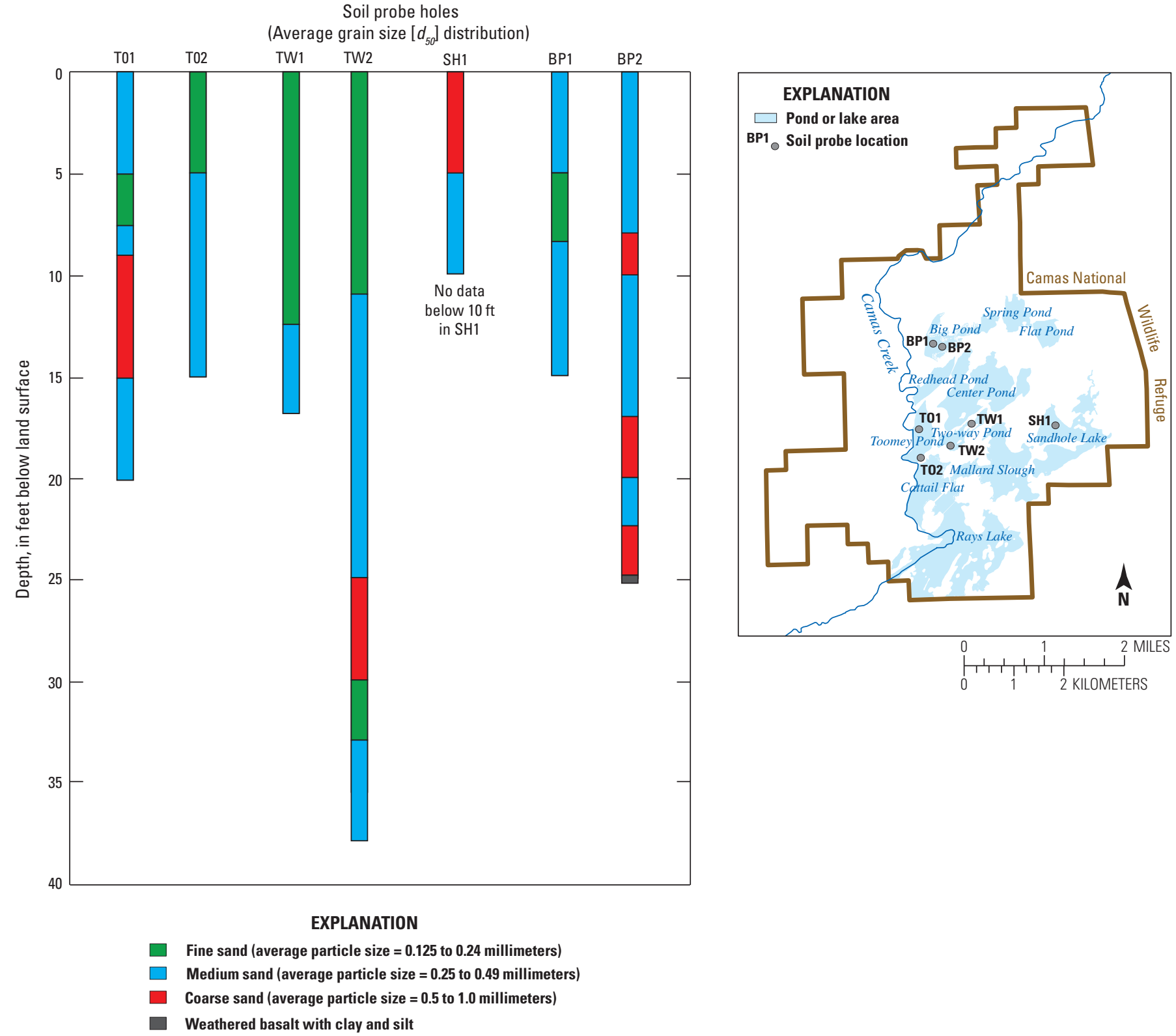

Figure 7. Vertical sediment profiles at soil probe sites, Camas National Wildlife Refuge, eastern Idaho. 
Soil probe site TW1 is located along the northeastern edge of Two-way Pond (fig. 1). Based on grain-size analysis from the six samples collected from plastic liners, sediment particles ranged from clay/silt to pebble (appendix A). The $\mathrm{d}_{50}$ ranged from 0.17 to $0.49 \mathrm{~mm}$, indicating that the average grain size was fine to medium sand (table 3 ). Based on the $d_{50}$ values, fine sand was recovered in the upper $12.5 \mathrm{ft}$; however, from 12.5 to $18 \mathrm{ft}$ the material grades to medium sand (fig. 7, table 3, appendix A).

Soil probe site TW2 is located along the southern edge of Two-way Pond (fig. 1). Based on grain-size analysis from 10 samples collected from plastic liners, particles ranged from clay and silt to pebble (appendix A). The $\mathrm{d}_{50}$ ranged from 0.19 to $0.77 \mathrm{~mm}$, indicating that the average grain size was fine to coarse sand (fig. 7, table 3). Similar to TW1, the upper $11 \mathrm{ft}$ of TW2 generally was consistent with a fine sand; however, from 11 to $38.5 \mathrm{ft}$, the material grades from medium to coarse sand and back to medium sand.

Sediment samples analyzed from soil probe sites TW1 and TW2 showed consistent $d_{50}$ values at both locations. The dominant sediment type for both soil probe locations was fine to medium sand; however, TW2 displays a $5 \mathrm{ft}$ lense of coarse sand from 25 to $30 \mathrm{ft}$. Sediment samples near the bottom of TW1 (15-18 ft) suggest higher concentrations of pebble size sediment. Sediment samples for TW2, based on $\mathrm{d}_{50}$ values (table 3), indicate sediment grades from fine to coarse and back to medium sand.

\section{Sandhole Lake Soil Probe}

The soil probe site at Sandhole Lake includes Sandhole Lake site 1 (SH1) that was drilled to a depth of $10 \mathrm{ft}$ bls (fig. 1). After 10 feet, samples could not be recovered because of a high water level that resulted in material sluffing out of the soil-probe recovery barrels. Sediment recovery for soil probe site SH1 ranged between 40 and 100 percent and the total combined recovery for all samples was about 64 percent, based on soil probe samples recovered in three plastic liners (table 2).

Soil probe site SH1 is located near the western edge of Sandhole Lake (fig. 1). Based on grain-size analysis from four samples collected from plastic liners, particles ranged from clay/silt to pebble (appendix A). The sample $d_{50}$ range of 0.29 to $0.52 \mathrm{~mm}$ indicated that the average sediment particle ranged from medium to coarse sand at this location (table 3). Based on the $d_{50}$ values, coarse sand occurs in the upper $5 \mathrm{ft}$; however, from 5 to $10 \mathrm{ft}$ the material grades to medium sand (fig. 7). Empirical evidence, however, indicates that Sandhole Lake drains water slowly (Brian Wehausen, Camas National Wildlife Refuge, oral commun., October 2015). This suggests that sediment at Sandhole Lake may become finer with depth or that finer sediment may be present in the southern and eastern parts in Sandhole Lake.

\section{Hydraulic Conductivity of Sediment}

The estimated hydraulic conductivities were based on the $\mathrm{d}_{50}$ and assumed textural maturity of the sediment. Sediments identified during grain-size analysis ranged from clay/silt to pebble, but the $d_{50}$ consisted of sand (fine, medium, and coarse). The textural maturity of sediment was characterized as fluvial, and was based on the surficial sediment indicated in figure 1 . This was consistent with the location of all of the monitoring wells in areas where the surface geology was fluvial and lake sediment (fig. 1), and grain-size analysis (appendix A) indicated that, except for sample BP2-R9, clay/ silt fractions were always $<20$ percent and usually $<5$ percent, suggesting that fluvial sediments were far more prevalent than lake sediments. Thus, all sediment samples were assumed to have a shape factor (C) for fluvial sediment (channel deposits; Fetter, 1994). The shape factor ' $C$ ' and exponent factor ' $\mathrm{j}$ ' were assigned constant values of 450 and 1.65, respectively, based on a sediment relation graph for channel deposits (Shepherd, 1989; Fetter, 1994).

Grain-size analyses defined a $d_{50}$ for sediment collected from soil probe cores ranging from 0.16 to $0.77 \mathrm{~mm}$ (table 3), resulting in a computed hydraulic conductivity range of about 20 to $290 \mathrm{ft} / \mathrm{d}$ (equation 1). The approximate hydraulic conductivity ranges for fine, medium, and coarse sand were 20 to $40 \mathrm{ft} / \mathrm{d}$, 50 to $140 \mathrm{ft} / \mathrm{d}$, and 140 to $450 \mathrm{ft} / \mathrm{d}$, respectively (equation 1). This assumes $d_{50}$ for fine sand ranges from 0.125 to $0.240 \mathrm{~mm}$, medium sand ranges from 0.250 to $0.490 \mathrm{~mm}$, and coarse sand ranges from 0.500 to $1.00 \mathrm{~mm}$. These computed hydraulic conductivity values were similar to those reported by other sources that calculated fine sand ranging from 0.1 to $60 \mathrm{ft} / \mathrm{d}$, medium sand ranging from 0.3 to $140 \mathrm{ft} / \mathrm{d}$, and coarse sand ranging from 0.3 to $1,700 \mathrm{ft} / \mathrm{d}$ (Domenico and Swartz, 1990, table 3.2).

Hydraulic conductivity ranged from 90 to $230 \mathrm{ft} / \mathrm{d}$ in $\mathrm{BP} 1$ and from 80 to $270 \mathrm{ft} / \mathrm{d}$ in BP2 (table 3). Medium and coarse sand, with estimated hydraulic conductivity as high as 230 and $270 \mathrm{ft} / \mathrm{d}$, were described near the base of BP1 and $\mathrm{BP} 2$, respectively.

The range in hydraulic conductivity from TO1 was 40 to $270 \mathrm{ft} / \mathrm{d}$, and the range in hydraulic conductivity associated with the $d_{50}$ in sediment from TO2 was 20 to $100 \mathrm{ft} / \mathrm{d}$ (table 3). Hydraulic conductivity seems to increase slightly with depth for both soil probe locations.

The range in hydraulic conductivity from TW1 was 20 to $140 \mathrm{ft} / \mathrm{d}$, and the range in hydraulic conductivity associated with the $d_{50}$ in sediment from TW2 was 30 to $290 \mathrm{ft} / \mathrm{d}$ (table 3). Hydraulic conductivity seems to increase slightly with depth for both soil probe locations; however, hydraulic conductivity in TW2 decreases below about $30 \mathrm{ft}$ BLS.

The range in hydraulic conductivity in SH1 was 60 to $150 \mathrm{ft} / \mathrm{d}$ (table 3). Hydraulic conductivity seems to decrease slightly with depth; however, because of limited depth for soil probe samples, estimates of hydraulic conductivity were limited to the upper 10 feet. 


\section{Groundwater Levels and Temperatures}

Data loggers were used to collect water-level and temperature measurements (figs. 8-14) from the seven screened intervals (figs. 2-5) in the four monitoring wells. The water level and temperature data may be retrieved from http://maps.waterdata.usgs.gov/mapper/ using the site identifiers in table 1. Data from site CNWR-P1 were missing because the water levels were below the altitude of the data logger, and data from site CNWR P2A were missing because of instrument damage.

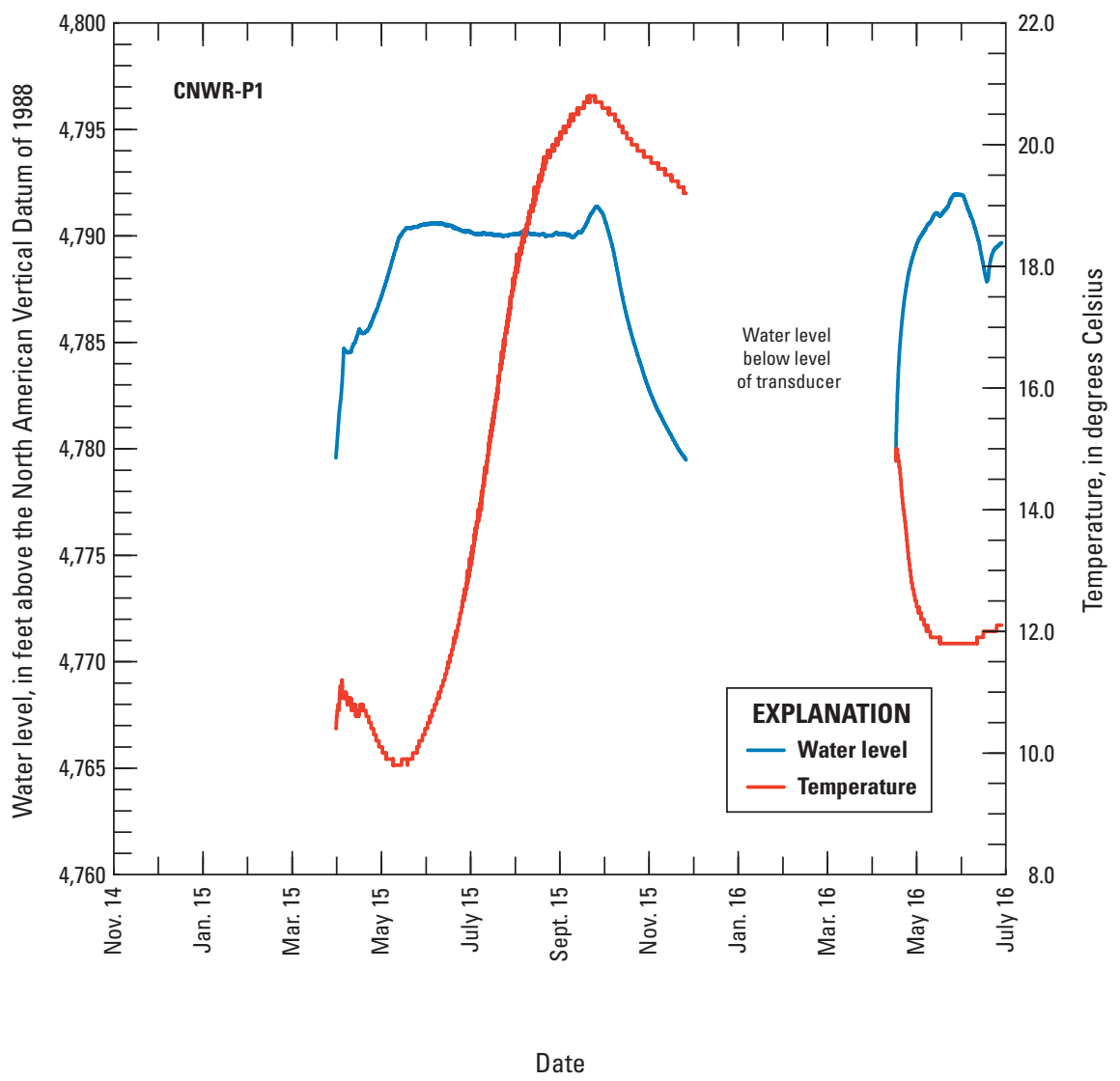

Figure 8. Water level and temperature at site CNWR-P1, Camas National Wildlife Refuge, eastern Idaho. 

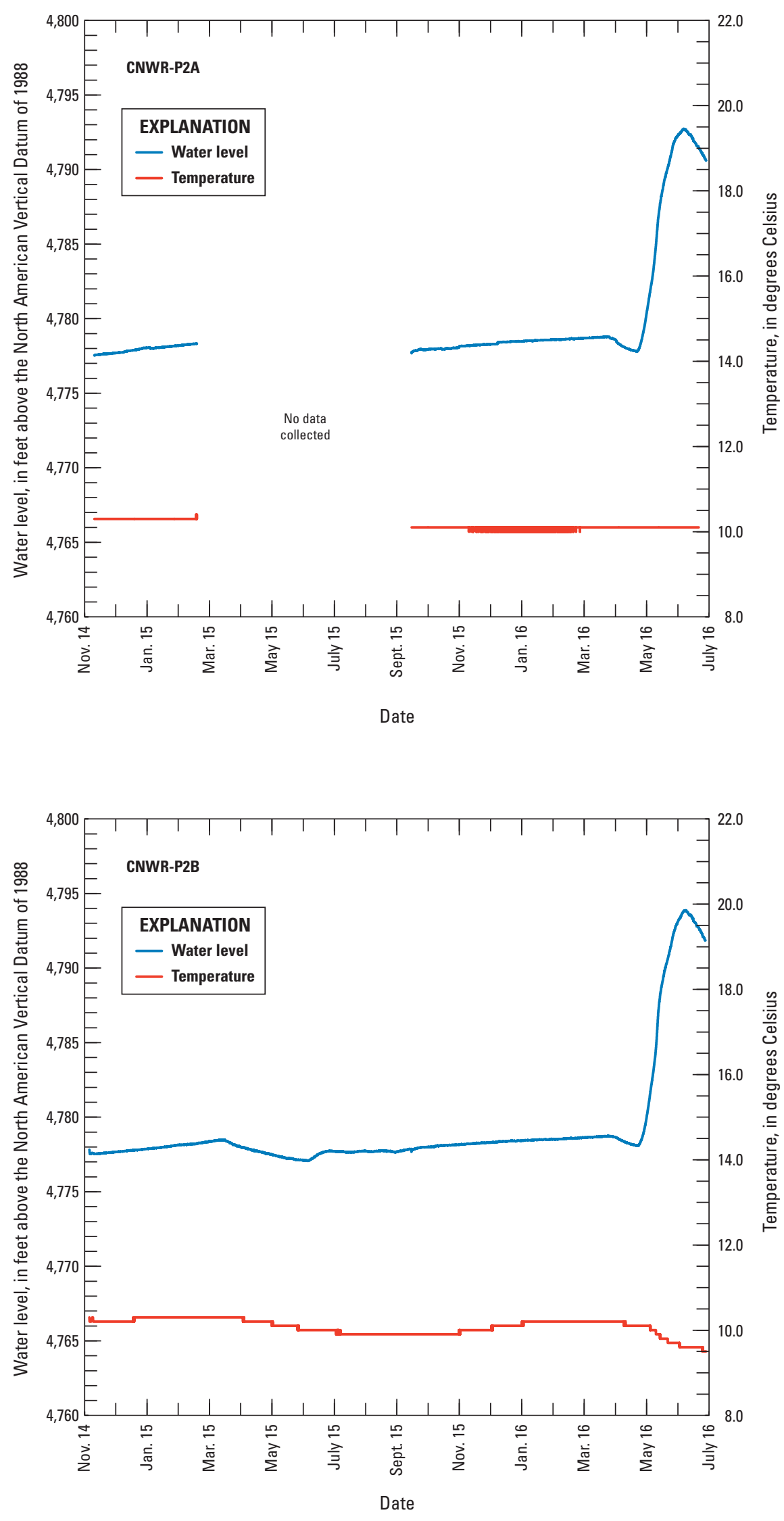

Figure 9. Water level and temperature at site CNWR-P2A, Camas National Wildlife Refuge, eastern Idaho.
Figure 10. Water level and temperature at site CNWR-P2B, Camas National Wildlife Refuge, eastern Idaho. 


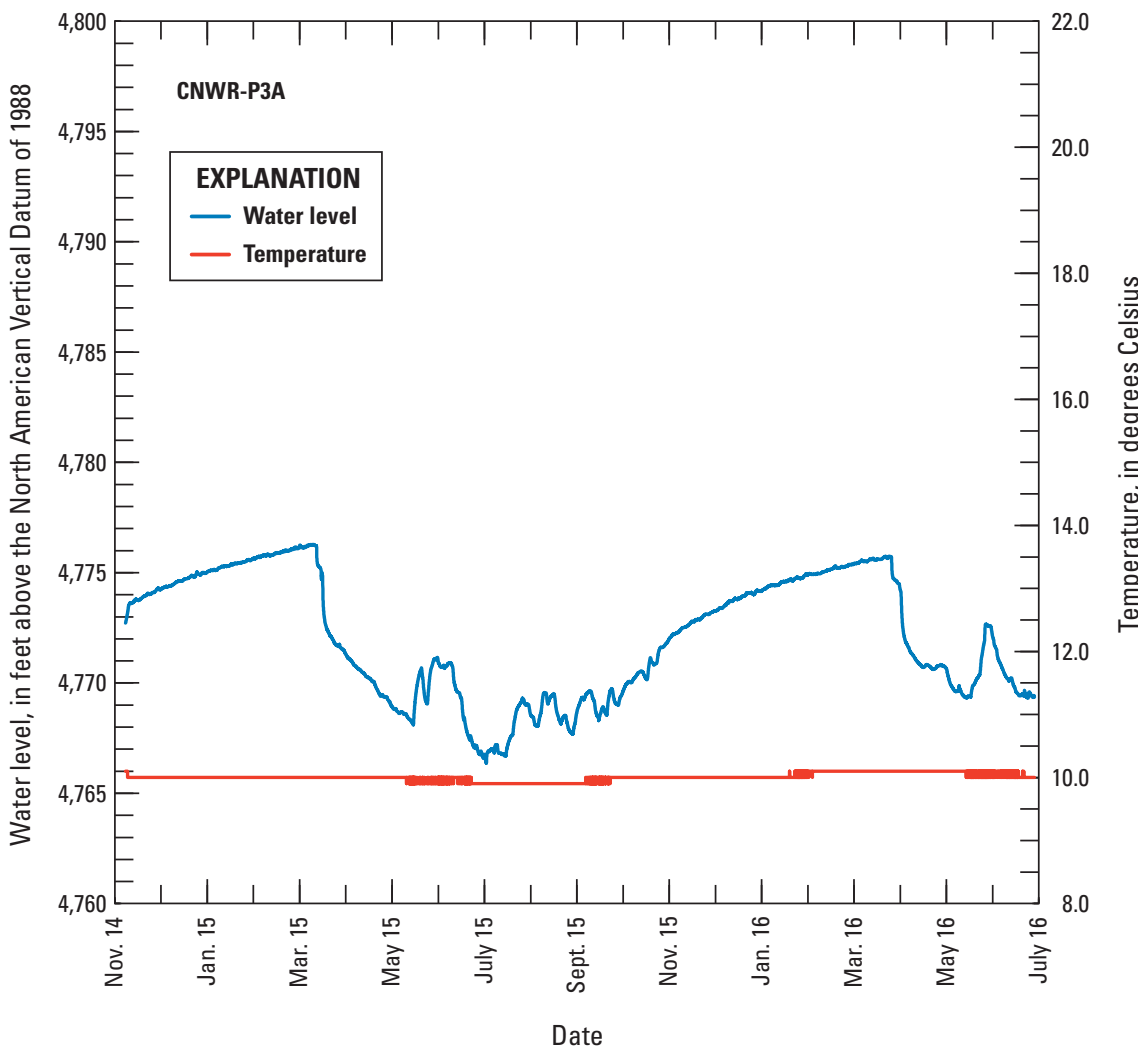

Figure 11. Water level and temperature at site CNWR-P3A, Camas National Wildlife Refuge, eastern Idaho.

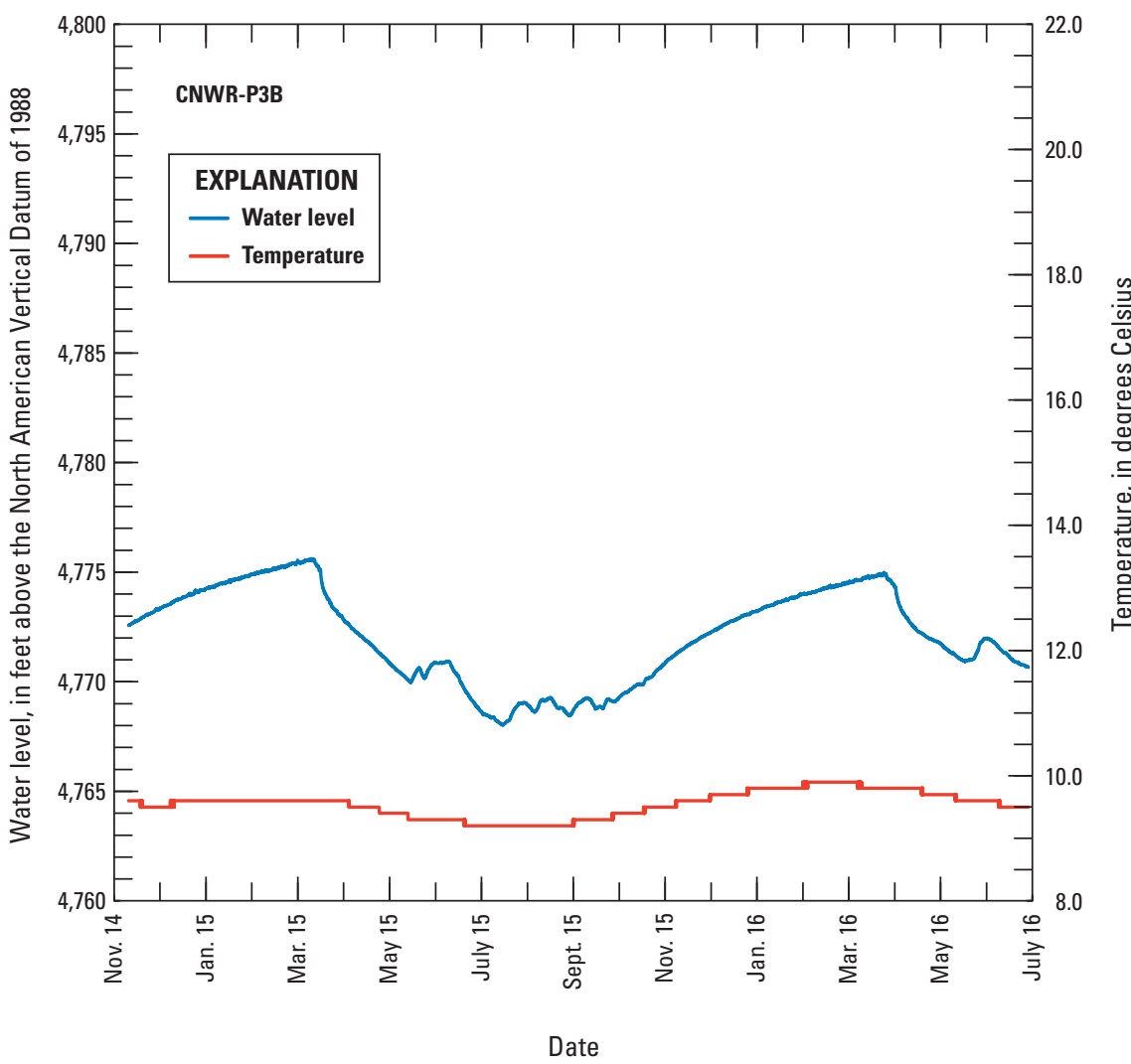

Figure 12. Water level and temperature at site CNWR-P3B, Camas National Wildlife Refuge, eastern Idaho. 

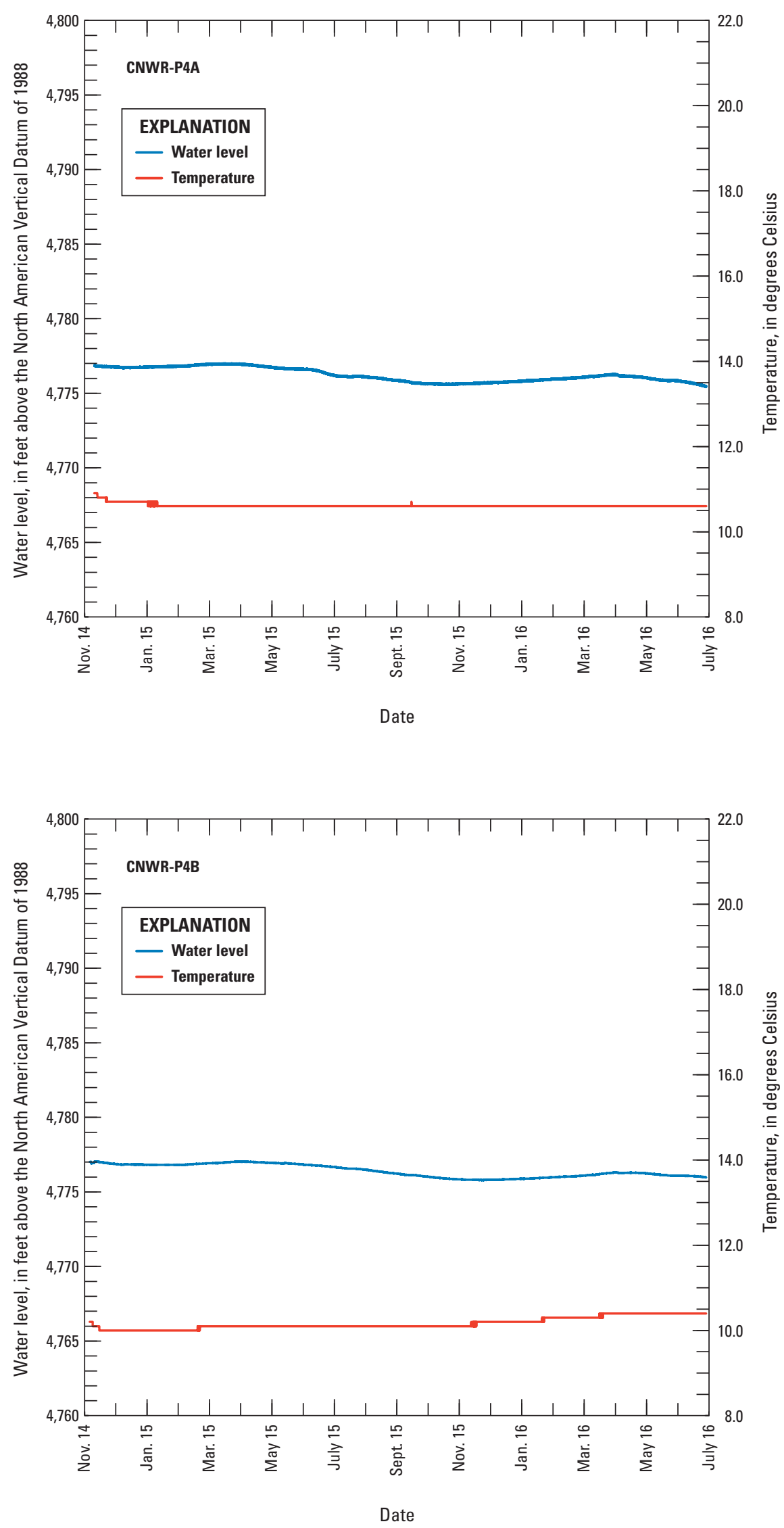

Figure 13. Water level and temperature at site CNWR-P4A, Camas National Wildlife Refuge, eastern Idaho.
Figure 14. Water level and temperature at site CNWR-P4B, Camas National Wildlife Refuge, eastern Idaho. 


\section{Summary}

The U.S. Geological Survey conducted a hydrogeologic study at the Camas National Wildlife Refuge in eastern Idaho to provide information for evaluating alternative water management options. The study entailed drilling four monitoring wells and collecting geophysical log data after drilling, collecting seven sediment cores with soil probes and analyzing grain-size of the sediment, estimating the hydraulic conductivity of the sediment samples, and measuring water levels and temperatures with data loggers installed in the seven screened intervals in the monitoring wells. Water level and temperature measurements from monitoring wells were collected continuously from November 2014 to June 2016.

Drillers' notes and geophysical log data were used to describe the type and distribution of sediment penetrated by monitoring wells. The hydraulic conductivity of sediment samples, extracted from sediment cores, was estimated from the average grain size and assumed textural maturity of the sediment. The estimated hydraulic conductivities ranged from 80 to 270 feet per day (ft/d) for Big Pond, 20 to $270 \mathrm{ft} / \mathrm{d}$ for Toomey Pond, 20 to $290 \mathrm{ft} / \mathrm{d}$ for Two-Way Pond, and 60 to $150 \mathrm{ft} / \mathrm{d}$ for Sandhole Lake.

\section{Acknowledgments}

Brian Wehausen, the manager of the U.S. Fish and Wildlife Service Camas National Wildlife Refuge, assisted in many aspects of the work contained in this report. Matthew J. Gilbert and Charlie J. Jones of the U.S. Geological Survey Idaho National Laboratory Project Office drilled the boreholes, prepared drillers' notes, and collected sediment cores. Amy J. Wehnke, also from the U.S. Geological Survey Idaho National Laboratory Project Office, installed piezometers in the boreholes and collected and processed the continuous water-level and temperature data.

\section{References Cited}

American Society of Civil Engineers, 1975, Sedimentation engineering: American Society of Civil Engineers, Hydraulics Division, Sedimentation Committee, Task Committee for the Preparation of the Manual on Sedimentation, Manuals and Reports on Engineering Practice, no. 54, 745 p.

American Society for Testing and Materials, 1985, Manual on test sieving methods-Guidelines for establishing sieve analysis procedures: American Society for Testing and Materials, STP 447 B, 43 p.
Bartholomay, R.C., Maimer, N.V., and Wehnke, A.J., 2014, Field methods and quality-assurance plan for water-quality activities and water-level measurements, U.S. Geological Survey, Idaho National Laboratory, Idaho: U.S. Geological Survey Open-File Report 2014-1146, 66 p., https://pubs. er.usgs.gov/publication/ofr20141146.

Domenico, P.A., and Schwartz, F.W., 1990, Physical and chemical hydrogeology: Hoboken, New Jersey, John Wiley \& Sons, Inc., 824 p.

Fetter, C.W., 1994, Applied hydrogeology (3d ed.): New York, Macmillan College Publishing Company, 691 p.

Garabedian, S.P., 1992, Hydrology and digital simulation of the regional aquifer system, eastern Snake River Plain, Idaho: U.S. Geological Survey Professional Paper 1408F, 102 p., 10 pls., https://pubs.er.usgs.gov/publication/ pp1408F.

Gillis, S., Knapp, B, Wolf, J., Izo, J., McElligott, K., Reader, J., Peterson, A., VanSant, D., and Weller, N., 2011, Indicators of climate change in Idaho: Moscow, University of Idaho, $15 \mathrm{p}$.

Goodell, S.A., 1988, Water use on the Snake River Plain, Idaho and eastern Oregon: U.S. Geological Survey Professional Paper 1408-E, 51 p., https://pubs.er.usgs.gov/ publication/pp1408E.

Henry, A.R., and Heitmeyer, M.E., 2014, Hydrogeomorphic evaluation of ecosystem restoration and management options for Camas National Wildlife Refuge: Greenbrier Wetland Services, Report No. 14-04, 93 p.

Keys, W.S., 1990, Borehole geophysics applied to groundwater investigations: U.S. Geological Survey Techniques of Water-Resources Investigations, book 2, chap. E2, 150 p., https://pubs.er.usgs.gov/publication/twri02E2.

Lewis, R.S., Link, P.K., Stanford, L.R., and Long, S.P., 2012, Geologic map of Idaho: Idaho Geological Survey Map 9, 1 sheet, accessed November 3, 2014, at http://www.idahogeology.org/Products/reverselook. asp?switch=title\&value=Geologic_Map_of_Idaho.

Rattray, G.W., and Ginsbach, M.L., 2013, Geochemistry of groundwater in the Beaver and Camas Creek drainage basins, eastern Idaho: U.S. Geological Survey Scientific Investigations Report 2013-5226, 70 p., https://pubs.er.usgs. gov/publication/sir20135226.

Shepherd, R.G., 1989, Correlations of permeability and grain size: Groundwater, v. 27, no. 5, p. 633-638. 
Spinazola, J.M., 1994, Geohydrology and simulation of flow and water levels in the aquifer system in the Mud Lake area of the eastern Snake River Plain, eastern Idaho: U.S. Geological Survey Water-Resources Investigations Report 93-4227, 78 p., https://pubs.er.usgs.gov/publication/ wri934227.

Stearns, H.T., Bryan, L.L., and Crandall, Lynn, 1939, Geology and water resources of the Mud Lake region, Idaho: U.S. Geological Survey Water-Supply Paper 818, 125 p., https:// pubs.er.usgs.gov/publication/wsp818.
U.S. Fish and Wildlife Service, 2012, Camas National Wildlife Refuge water resource inventory and assessment: Portland, Oregon, U.S. Fish and Wildlife Service, Water Resources Branch, 54 p.

U.S. Geological Survey, 2011, Log archiver system: U.S. Geological Survey Web site, accessed July 27, 2016, at http://logarchiver.usgs.gov/. 


\section{Appendix A. Results of Particle-Grain Size Analyses on 49 Sediment Samples That Were Separated from the Seven Soil Probe Sediment Cores}

Appendix A is a PDF file and can be downloaded at http://dx.doi.org/10.3133/ds1024. 

Publishing support provided by the U.S. Geological Survey Science Publishing Network, Tacoma Publishing Service Center

For more information concerning the research in this report, contact the Director, Idaho Water Science Center

U.S. Geological Survey

230 Collins Road

Boise, Idaho 83702

http://id.water.usgs.gov 
